ANL/OTEC-BCM-011

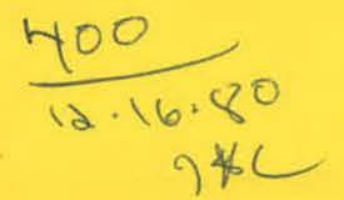

R669

ANL/OTEC-BCM-011

\title{
MICRO- AND MACROFOULING IN THE OTEC PROGRAM: AN OVERVIEW
}

Ralph Mitchell and Peter H. Benson

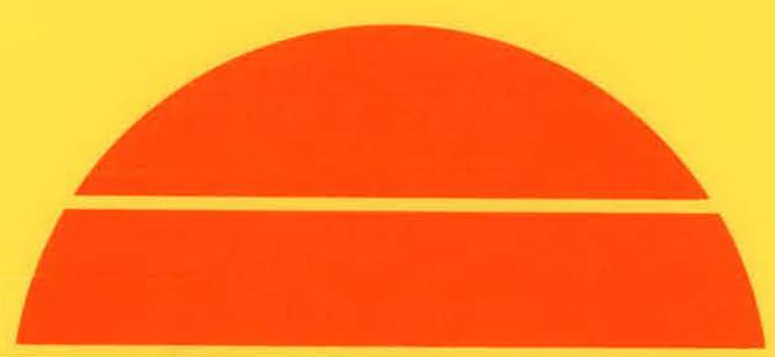

Argonne National Laboratory

9700 South Cass Avenue

Argonne, Illinois 60439
Prepared for the

U. S. Department of Energy

Division of Central Solar Technology under Contract W-31-109-Eng-38 


\section{DISCLAIMER}

This report was prepared as an account of work sponsored by an agency of the United States Government. Neither the United States Government nor any agency Thereof, nor any of their employees, makes any warranty, express or implied, or assumes any legal liability or responsibility for the accuracy, completeness, or usefulness of any information, apparatus, product, or process disclosed, or represents that its use would not infringe privately owned rights. Reference herein to any specific commercial product, process, or service by trade name, trademark, manufacturer, or otherwise does not necessarily constitute or imply its endorsement, recommendation, or favoring by the United States Government or any agency thereof. The views and opinions of authors expressed herein do not necessarily state or reflect those of the United States Government or any agency thereof. 


\section{DISCLAIMER}

Portions of this document may be illegible in electronic image products. Images are produced from the best available original document. 
The facilities of Argonne National Laboratory are owned by the United States Government. Under the terms of a contract (W-31-109-Eng-38) among the U. S. Department of Energy, Argonne Universities Association and The University of Chicago, the University employs the staff and operates the Laboratory in accordance with policies and programs formulated, approved and reviewed by the Association.

\section{MEMBERS OF ARGONNE UNIVERSITIES ASSOCIATION}

The University of Arizona

Carnegie-Mellon University

Case Western Reserve University

The University of Chicago

University of Cincinnati

Illinois Institute of Technology

University of Illinois

Indiana University

The University of Iowa

Iowa State University
The University of Kansas

Kansas State University

Loyola University of Chicago

Marquette University

The University of Michigan

Michigan State University

University of Minnesota

University of Missouri

Northwestern University

University of Notre Dame
The Ohio State University

Ohio University

The Pennsylvania State University

Purdue University

Saint Louis University

Southern Illinois University

The University of Texas at Austin

Washington University

Wayne State University

The University of Wisconsin-Madison

\section{NOTICE}

This report was prepared as an account of work sponsored by an agency of the United States Government. Neither the United States Government or any agency thereof, nor any of their employees, make any warranty, express or implied, or assume any legal liability or responsibility for the accuracy, completeness, or usefulness of any information, apparatus, product, or process disclosed, or represent that its use would not infringe privately owned rights. Reference herein to any specific commercial product, process, or service by trade name, mark, manufacturer, or otherwise, does not necessarily constitute or imply its endorsement, recommendation, or favoring by the United States Government or any agency thereof. The views and opinions of authors expressed herein do not necessarily state or reflect those of the United States Government or any agency thereof.

Printed in the United States of America

Available from

National Technical Information Service

U. S. Department of Commerce

5285 Port Royal Road

Springfield, VA 22161

NTIS price codes

Printed copy: A04

Microfiche copy: A01 
ANL/OTEC-BCM-011

\title{
ARGONNE NATIONAL LABORATORY \\ 9700 South Cass Avenue \\ Argonne, T11inois 60439
}

\author{
MICRO- AND MACROFOULING IN THE \\ OTEC PROGRAM: AN OVERVIEW
}

\author{
Ral'ph Mitchell \\ Division of Applied Sciences \\ Harvard University \\ Cambridge, Massachusetts 02138 \\ and
}

Peter H. Benson

Division of Environmental Impact Studies

Argonne National Laboratory

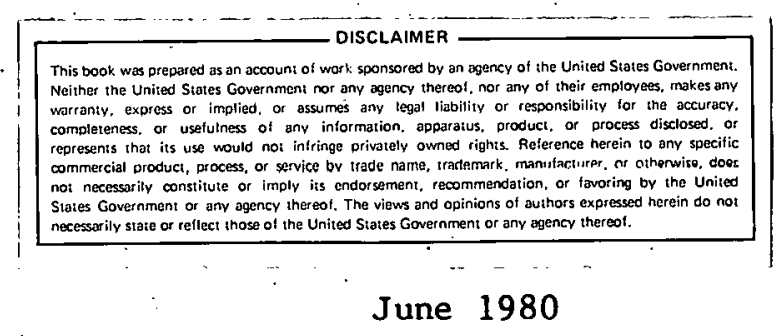




\section{PREFACE}

This report is intended to introducc the reader, unfamiliar with biofouling, to the fundamentals of this biological phenomenon with specific reference to OTEC and its unique set of circumstances. It is neither a comprehensive review of the biofouling literature, nor a definitive compilation of existing OTEC biofouling data. It is meant to define, in general terms, potential biofouling problem areas of greatest impact to practical OTEC operation. As such, the report summarizes the results of DOE-funded, short-term OTEC biofouling tests and experiments, reveals areas of uncertainty and limitations, and indicates what needs to be done to resolve these issues :

Biofouling control methods applicable to conventional, coastal-sited power-generating plants may not be effective or prove practical on OTEC. There are no pat answers to biofouling control, and areas of further research and development to ensure viable OTEC operation are discussed. Although a great deal has been accomplished in the microfouling area since the OTEC Biofouling, Corrosion and Materials (BCM) Workshop at Rosslyn, Virginia, in 1979, macrofouling under OTEC operational conditions still remains an unknown. This report stresses the need to establish long-term effects of micro- and macrofouling on OTEC performance and to determine the effectiveness of control methods used during these studies.

We wish to acknowledge the efforts of $E$. H. Kinelski, U. S. Department of Energy, and J. E. Draley, Argonne National Laboratory. Without the initiative and support of $\mathrm{Mr}$. Kinelski and the able technical direction of Dr. Draley, much of the biofouling work reported here could not have been accomplished. 
TABLE OF CONTENTS

$\underline{\text { Page }}$

EXECUTIVE SUMMARY $\ldots \ldots \ldots \ldots \ldots \ldots \ldots \ldots \ldots \ldots \ldots \ldots \ldots \ldots \ldots \ldots \ldots \ldots \ldots$

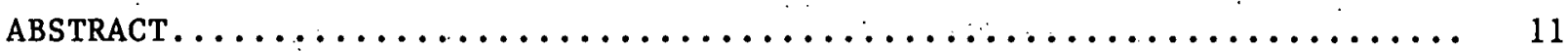

I. INTRODUCTION. ................................. 11

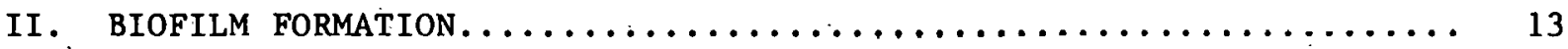

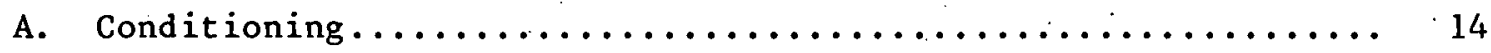

B. Microbial Colonization of the Surface............... 14

C. Growth of the Biofilm....................... 15

D. Microfouling and Scale Formation................. 17

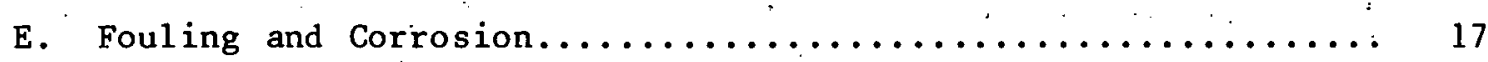

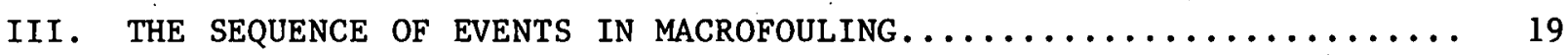

IV. ASSESSMENT OF MICROFOULING $\ldots \ldots \ldots \ldots \ldots \ldots \ldots \ldots \ldots \ldots \ldots \ldots \ldots \ldots$

A. Heat-transfer Monitoring Devices (HTMs) ............... 21

B. Biological Measurements....................... 22

C. Nondestructive Assays.......................... 24

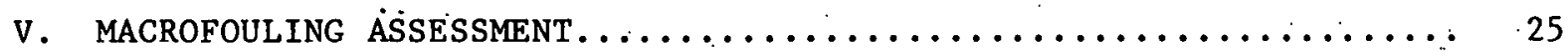

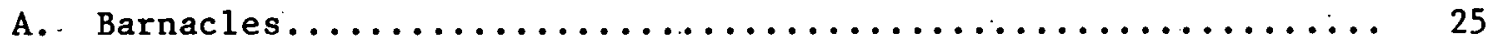

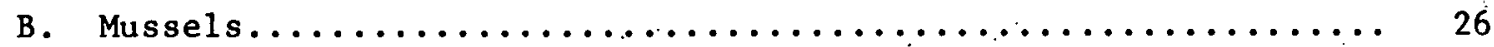

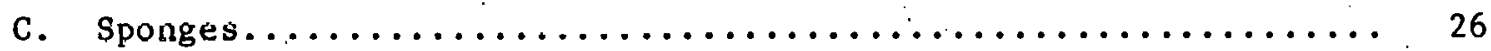

D. Sea Anemones and Hydroids....................... 26

E. Bryozoans..................................... 26

F. Serpulids............................... 27

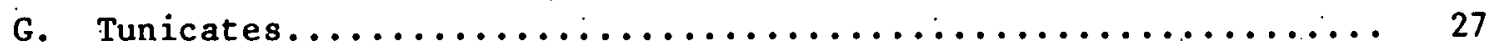

H. Amphipods .................................. 27

I. Algae....................................... 28

J. Stone-boring Mollusks.......................... 28 
TABLE OF CONTENTS

Page

VI: ENVIRONMENTAL FACTORS AFFECTING FOULING................ 29

A. Water Chemistry/Nutrients..................... 29

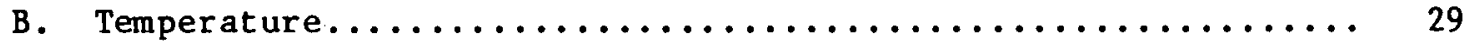

C. Pressure................................. 30

D. Water Depth......................... 30

E. Water Velocity................................ 31

F. Material Surfaces........................ 32

G. Mechanical Design.......................... 33

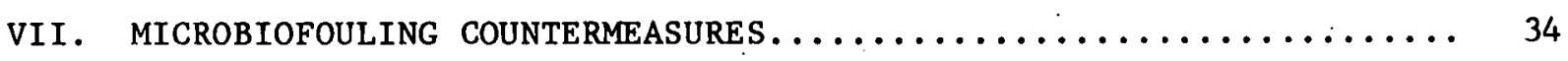

A. Flow-driven Brushes......................... 34

B. Amertap Recirculating Rubber Balls................ 35

C. Chemical Treatment......................... 36

D. Slurry Cleaning........................... 37

E. U1trasonic cleaning ........................ 37

F. Plaque Formation........................... 38

VIII. MACROFOULING COUNTERMEASURES $\ldots \ldots \ldots \ldots \ldots \ldots \ldots \ldots \ldots \ldots \ldots \ldots$

A. Toxic Coatings............................. 39

B. Nontoxic Coatings.......................... 40

C. Toxic Alloys............................. 40

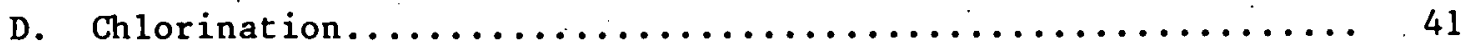

E. Ozone................................... 43

F. Ultraviolet Irradiation..................... 43

G. Ultrasonic Biofouling Prevention................. 45

H. Cathelco................................ 45

I. Screens................................ 46

J. Concrete and Plastic Structures.................. 46

K. Mechanical Cleaning......................... 47 


\section{LIST OF FIGURES}

No.

Title

Page

1. The Relationship between Heat Transfer and Biofilm Thickness......

2. Diagrammatic Thermal Resistance Curves Observed during Cleaning

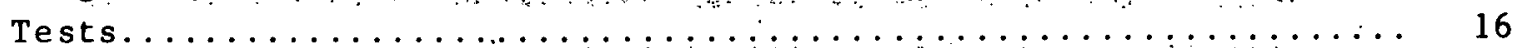

3. Biofouling Mass as a Function of Depth in the Tongue of the Ocean.. 30

4. Comparison of Fouling Parameters Relative țo the OTEC Limit...... 35

\section{LIST OF: TABLES}

No. Title

Page

1. Stages of Primary Microbial Film Development............. 13

2. Development of the Fouling Community................... 19

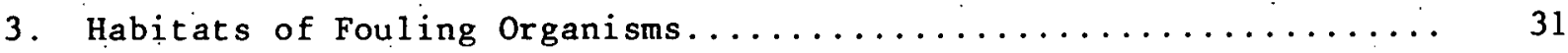

4. Initial and Operating Cost of a UV Water-treatment System for a

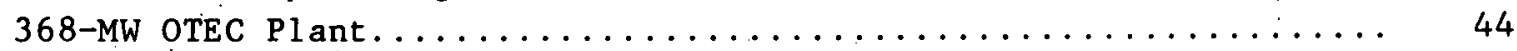

5. Physical Properties of Organotin and Conventional Laminates..... 47 
THIS PAGE

\section{WAS INTENTIONALLY LEFT BLANK}




\section{MICRO- AND MACROFOULING IN THE OTEC PROGRAM: AN OVERVIEW}

Ralph Mitchell and Peter H. Benson

\section{EXECUTIVE SUMMARY}

We have reviewed biofouling information relevant to the OTEC program. This report reviews the mechanisms of formation of micro and macrofouling, the environmental factors controlling fouling, means of assessment, and available control measures. Formation of biofilms (microfouling) can be divided into four stages: attachment of a conditioning film, colonization by pioneer bacteria, development of a secondary biofilm population, and a final stage involving the adhesion of debris and growth of the bacteria on the biofilm matrix. The relationship between heat-transfer resistance and biofilm development is not thoroughly understood. Additional research is needed to explain the interaction between biochemical events on heat-transfer surfaces and thermal, resistance.

Macrofouling is expected to occur on all unprotected OTEC surfaces in contact with seawater. Marine macrofouling results from the attachment and growth of invertebrate larvae and the spores of algae on submerged surfaces. The macrofouling process is complex and cannot be controlled by preventing bacterial slime formation in OTEC heat exchangers.

Heat-transfer monitoring devices (HTMs) are used to integrate the effects of thin biofilms on thermal resistance. Biochemical methods are available and being developed to assess the biological processes occuring during biofilm formation. Total organic carbon correlates extremely well with thermal resistance. Scanning electron microscopy provides a qualitative and semiquantitative measure of the attachment and growth of microbes on, the surface in contact with the seawater. More sophisticated techniques for the assay of biomass population structure and polymer production in the OTEC microfouling. program are being developed by $D$. White at Florida State University. Nondestructive methods of following microfouling processes are available." These include internal-reflection infrared spectroscopy, frictional resistance, and possibly ulirasound. It would be advantageous if these and other nondestructive methods of measurement were applied in the OTEC program. However, such research studies are presently outside the scope of the OTEC program.

No single countermeasure has been qualified to control microbiofouling. Titanium pipes havè been kept clean for 70 days using flow-driven brushes. However, the system suffers from serious problems related to macrofouling. Ultimately the buildup of macroorganisms can completely stop the action of the brushes. 
The Amertap rubber-ball system appears to be more flexible and more reliable as a means of controlling microbiofouling. Preliminary tests have shown that a conventional Amertap system can maintain shell and tube model heat exchangers free of microfouling for short periods of time. Extensive tests in Japan have resulted in modification of the process to include carborundum balls. The Amertap system provides a potentially promising approach to the control of microbiofouling. Long-term tests will be required at the Seacoast Test Facility and elsewhere.

Chemical cleaning offers the important advantage of being able to maintain heat exchangers of any geometry free of microbiofouling. Chlorination is currently being tested with some degree of success. If chlorination is unacceptable, then other chemicals including detergents are available. In view of environmental constraints, it will probably be necessary to modify the cleaning system to allow isolation of heat-exchanger modules and recycling of chemicals.

Evidence is accumulating that plaque deposits build up on heat-exchanger surfaces following extended periods of cleaning. The plaque appears to be a mixture of microbes, their exopolymers, and inorganic debris. It is not known if plaque formation occurs at all locations and on all metal surfaces. Longterm cleaning tests will be required to determine if plaque accumulation is a problem on OTEC heat-exchanger surfaces and to establish methods of either preventing these deposits from occurring or finding a means of removing the plaque after it has developed.

Predictive forecasts of macrofouling rates can be made using dry-weight measurements. In addition, the potential for development of specific macrofouling communities on stationary structures $c$ an be determined by measuring species abundance on panels over a period of one to two years. The kinetics as well as the dominance of organisms present in both microfouling and macrofouling communities are controlled by a range of environmental factors. Natural environmental conditions, such as water chemistry and ambient temperature, are determined by choice of location. However, fouling is also dependent on flow velocity, choice of metal, and other design factors. Both microfouling and macrofouling can be minimized by making appropriate design decisions. For example, the choice of geometry of heat exchangers is critical. Heat-transfer surfaces that are designed to enhance the surface without allowing for adequate cleaning of the enhanced area will present a serious problem. The relationship between macro- and microfouling needs to be determined.

No single control measure for macrofouling is available to the entire OTEC system. The emphasis, however, needs to be on prevention of settlement of macrofouling larvae rather than on cleaning. Once the larvae have settled, they are much more resistant to control. Adult forms frequently leave residual dead material behind that may seriously interfere with performance of the entire OTEC system. A number of different state-of-the-art methods are available to control macrofouling. The 1 ife of commercial copper-based paints is 
too short to be useful for OTEC. However; rubber- or plastic-based coatings impregnated with organo-tin compounds may afford protection for as long as 10 years. Copper alloys can also provide some macrofouling protection; they require that care be taken to avoid galvanic corrosion. Chlorination is commonly used to control macrofouling in power plants; however, prevention of larval settlement requires continuous chlorination. Economic and environmental constraints may make the use of chlorine for this purpose in the OTEC program unacceptable. High-intensity ultrasound removal and ultraviolet irradiation prevention have also been tested as a means of controlling macrofouling. Both methods have excessive energy requirements and are limited in application, suggesting that they are not applicable to OTEC.

The prevention of macrofouling on intake screen systems can possibly be achieved by the use of copper alloys. Concrete structures can potentially be protected by impregnation with organo-tin compounds. The Navy is currently experimenting with organo-tins incorporated chemically in glass-reinforced plastics. 
THIS PAGE

WAS INTENTIONALLY

LEFT BLANK 


\section{ABSTRACT}

This report reviews the mechanism of formation and environmental factors affecting marine biofouling. Methods of biofouling assessment, known and potential biofouling impacts upon plant performance, and control measures applicable to OTEC are also discussed. Areas of uncertainty and the needs for continuing $R \& D$ effort to resolve such issues are indicated.

\section{INTRODUCTION}

This report is prepared at the request of the Department of Energy, Division of Ocean Energy Systems. The objective of this review is to summarize the state of the art in biofouling of materials in the sea and of methods available to keep these materials free of fouling.

Biofouling is a general term used to describe all forms of biological materials deposited or formed on immersed materials. There are many kinds and sources of fouling, and the problem occurs in both heat exchangers and other equipment throughout the power industry. The fouling process is not well understood. However, biologists classify marine fouling as either micro or macro. Microfouling is caused by the growth of microbes and their products on the material surface. Since these organisms are common in the marine habitat, large quantities of microbes can be expected to deposit on any surfaces in contact with the sea. These slimes grow rapidly and are capable of retarding heat transfer, even in layers as thin as $10 \mu \mathrm{m}$.

Macrofouling commonly occurs on equipment placed in water at depths of less than $300 \mathrm{ft}$. It is relatively light below $300 \mathrm{ft}$ until the seafloor is reached, where it increases. Auxiliary equipment including screens, piping, tube sheets, and other components of the OTEC system can be expected to macrofoul unless they are protected. Under open ocean conditions, the organisms found most commonly are hydroids, mussels, tunicates, barnacles, and bryozoans. Species dominance will depend on location, with hard corals also anticipated as a major problem at tropical OTEC sites.

Control of microfouling on heat-exchanger surfaces is of critical importance to the OTEC program. Very small quantities of slime are sufficient to seriously limit heat transfer. This relationship between fouling resistance caused by microbial slime and inhibition of heat transfer is shown in Fig. 1 . The degree of heat-transfer resistance $c$ an be related directly to the buildup of slime layers. A slime less than 100 microns thick is sufficient to yield Rf values in excess of 0.0005 on metal surfaces. Since microorganisms grow rapidly in warm ocean waters, this phenomenon is of prime importance in the OTEC program. Microbes should grow well in the warm surface water used for heat transfer by OTEC evaporators. Slime films can therefore be expected to 
be a major problem on OTEC evaporators. Condensers will use cold water from more than $2000 \mathrm{ft}$ deep, which is much less active biologically. However, these waters are nutrient rich and would support the growth of biofilms. Although we anticipate that the growth rate of condenser biofilms will be slower than those on evaporator surfaces, only a minimal amount of information about the potential for microfilm formation on OTEC condensers is available.

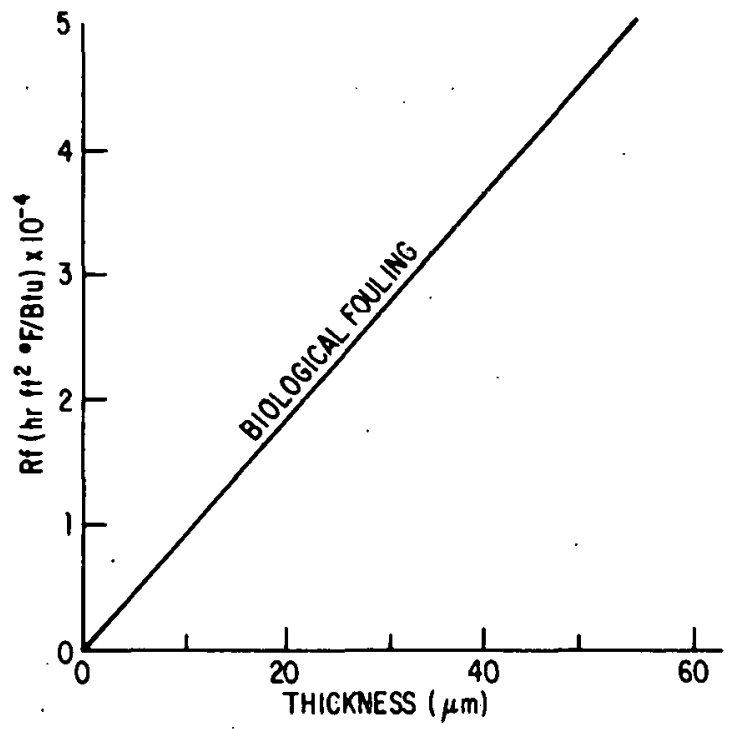

Fig. 1

The Relationship between Heat Transfer and Biofilm Thickness. Adapted from Little, B. and D. Lavoie, "Gulf of Mexico Ocean Thermal Energy Conversion (OTEC) Biofouling and Corrosion Experiment," in Proceedings of the Ocean Thermal Energy Conversion (OTEC) Biofouling, Corrosion and Materials Workshop, Rosslyn, Va., ANL/OTEC-BCM-002 (Jan 8-10, 1979).

In order to develop adequate countermeasures against microfouling, we need to know the mechanism of film formation and the relationship between the formation of the biofilms and environmental conditions. In this report we will discuss some of the methods used for evaluation of biofilm kinetics and a number of hypotheses formulated to describe the processes leading to biofilm formation. The OTEC countermeasures program will be described, and an attempt will be made to identify those measures that appear at this time to be most promising .

The influence of macrofouling on OTEC components is a serious problem. It will be essential to control the settlement and growth of macrofouling organisms on all components in contact with seawater. Macrofouling will cause restriction of fluid flow, turbulence, and other problems in the piping systems. It will also cause restriction, clogging, or jamming of valves, screens, pumps, and tubesheets. The problem will be aggravated when the flow rate of water through the system is slow or during intermittent operation. No simple solution to macrofouling can be expected for the OTEC system because of the wide variety of auxiliary equipment. Different control measures may be required.for individual components. An overall biofouling control program will require specific solutions to individual problems. Some of the solutions available are discussed in this report.

It is planned to initiate an OTEC pilot-plant preliminary design in FY/1981. This plant design will bring the entire OTEC system together. The 
developmental work in the biofouling program is directed toward a successful design of the pilot plant. Accordingly, microfouling countermeasures must be effective in maintaining an Rf approximating 0.0001-0.0003 on heat-transfer surfaces. In addition, all other components in contact with seawater must be maintained free of macrofouling. In view of the high cost of the proposed pilot plant, low-risk countermeasures must be developed for control of both microfouling and macrofouling and these measures must be economically and environmentally acceptable. Factors involved in the choice of these countermeasures are discussed in this report.

\section{BIOFILM FORMATION}

The attachment of bacteria to material surfaces in seawater is responsible for the process known as microfouling. The control of microfouling depends on understanding the sequence of events leading to the development of these microbial films. Since bacteria basically act as colloidal particles, their interaction with solid surfaces $c$ an be anticipated on the basis of colloidal theory. However, bacteria do not behave as typical colloids. They are capable of independent locomotion, of growth, and of forming different shapes. In addition, most microorganisms exude large quantities of extracellular polymeric material, which aids in the anchoring of microbes to a surface. The interaction between these colloidal and biological factors influences microbes colonizing surfaces in the sea. Significant film formation may occur in hours or may take weeks, depending on a number of factors in the water column. In nutrientrich coastal waters, a rapid increase in film thickness occurs with biofilms more than 300 microns thick observed in less than a week. The environmental conditions controlling biofilm formation are discussed later in this report.

The formation of biofilm can be divided into the four stages shown in Table 1. Apparently no specialized microbes are involved in the formation of biofilms in seawater. The same microbes are found in most habitats, and a wide variety of common marine forms are capable of attachment and growth on all materials exposed to seawater.

TABLE 1. Stages of Primary Microbial Film Developmenta

\begin{tabular}{ll}
\hline Stage & Comments \\
\hline 1. Conditioning & $\begin{array}{l}\text { Chemical adsorption; organisms not directly in- } \\
\text { volved; instantaneous reaction. }\end{array}$ \\
2. Colonization by "pioneer" & $\begin{array}{l}\text { Fast-growing bacterial periphytes, attracted } \\
\text { to, or otherwise respond to conditioned surface. } \\
\text { Become well established in matter of hours. }\end{array}$ \\
3. Colonization by other & $\begin{array}{l}\text { Other bacteria, microalgae, and protozoa may } \\
\text { develop extensively in a matter of days. }\end{array}$ \\
4. Accumulative & $\begin{array}{l}\text { Adhesion of particles, dead cells, and detritus. } \\
\text { May begin when the pioneer film develops. }\end{array}$
\end{tabular}

${ }^{a}$ Corpe, W. A. 1977. Marine Microfouling and OTEC Heat Exchangers, in Proceedings of the Ocean Thermal Energy Conversion (OTEC) Biofouling and Corrosion Symposium, Robert, H. Gray, Ėd., Pp. $31-44$. 


\section{A. Conditioning}

Adhesion of microbes to metals in seawater is always preceded by absorption of multilayers of natural complex polymers.* These films determine the success and permanence of attachment of the microbes. Such conditioning films are usually composed of high-molecular-weight glycoproteins and proteoglycans. Baier has used nondestructive analytical techniques to show that there is an empirical correlation between the solid's critical surface tension and its ability to attach microfouling. He has shown that heat-transfer surfaces in seawater acquire adsorbed films dominated by glycoproteins soon after placement in the water. However, different strengths of adhesion were noted.

Film layers acquired on high-surface-energy, high-polarity substrata are flattened and tightly adherent in contrast with more weakly bound, but occasionally thicker layers accumulated in the same amount of time, on lowsurface-energy, nonpolar surfaces. High-surface-energy surfaces, especially those dominated by high-polarity groups, demonstrate maximal subsequent microfouling. In contrast, low-surface-energy layers bind the micromolecular conditioning film more loosely and are therefore less susceptible to microfouling. $* *$ Thus, lower-energy surfaces are more resistant to biofouling accumulation and/or persistence, and may be easier to clean. However, very low-energy surfaces, typically those of fluorocarbon composition, apparently bind natural molecules as strongly as some of the higher-energy surfaces. Thus, if microfouling is to be controlled using surface active coatings, only those coatings with an intermediate critical surface-tension range would minimize the settling of microbes and the ultimate development of a biofilm. The possibility of controlling the conditioning film as a means of preventing biofouling is discussed in more detail in the countermeasures section of this report.

B. Microbial Colonization of the Surface

The concentration of polymers from seawater on a material surface acts as a primary site of nutrient concentration for microbes, and we see intensified microbial activity at these sites. The movement of water across the metal surface provides increased opportunity for microbes to approach the solid-liquid interface. They are attracted to the surface and ultimately settle within a few hours. Attachment is complicated by electrostatic forces at the solid-liquid interface. The bacteria are held at some distance from the surface by electrical, double-layer repulsion energies.t In this reversible phase of biofilm attachment, the bacteria are only held weakly at the solid surface. They exhibit Brownian motion and can easily be removed.

The pioneer film of bacteria attaches irreversibly to the surface as a result of production of extracellular polymer by the bacteria. - Synthesis of

*Baier, R. E., E. G. Shafrin and W. A. Zisman, 1968. Adhesion, Mechanisms that Assist or Impeded.

Science $162: 1360$.

**Baier, R. E. Proceedings International Heat Transfer Conference, Rensselaer Polytechnic Institute, 1979.

†Marshall, K. C. Interfaces in Microbial Ecology. Harvard University Press, 1976. 
these extracellular fibers allows the bacteria to bridge the electrical repulsion barrier between the material surface and the bacterial cell. These fibrils attach the bacteria firmly to the metal surface. The microbial polymers appear to be polysaccharides or glycoproteins. These bacterial polymers act as strong adhesives and guarantee that the pioneer population of bacteria in a biofilm will be permanently attached to the material surface, insulating that surface from the water column.

C. Growth of the Biofilm

The attachment of a primary film of bacteria to a surface is normally followed by the development of other groups. of microbes in rapid succession. The -primary colonizers are characterized by their ability to produce large quantities of polymeric bridging material. At a later stage, after some days, other bacteria, particularly stalked and filamentous forms, colonize the surface.

In flowing-seawater systems, microbes attached to material surfaces gain most benefit from the continual input of low levels of nutrients from the water.* The microbes grow as a response to nutrients flowing past the surface continuously. At the same time, they produce large quantities of polymers, which trap other microbes and debris flowing past the surface. Typically, we see a rapid ecological succession of microbes on the surface, together with a rapid rate of growth once the metal surface has been covered with a monolayer of pioneer microbes. Because of the large number of microbes on the surface, antagonistic interactions probably occur. However, we know very little about interactive microbial activities in these biofilms.

It is known, however, that the metabolic efficiency of biofilms is ultimately limited by the slow diffusion of nutrients or oxygen into the inner portion of the film. Ultimately, part of the biofilm becomes biologically inactive after the attainment of the critical film thickness. This phenomenon would only be observed on OTEC heat-exchanger surfaces during periods of shutdown when the water flow rate would be slow or flow was stopped.

It must be emphasized, however, that the primary film rarely is lost, so that the regrowth process is very rapid. The rate-limiting step in biofilm development is the attachment of the conditioning film with a second limitation caused by the attachment of the primary microbial film. The secondary film can attach and regrow very rapidly indeed, probably within two to five days.

*Märshall, K. C. in R. Mitchell, (Ed.). Water Pollution Microbiology, Vol. II. Wiley \& Sons, New York, 1978. 


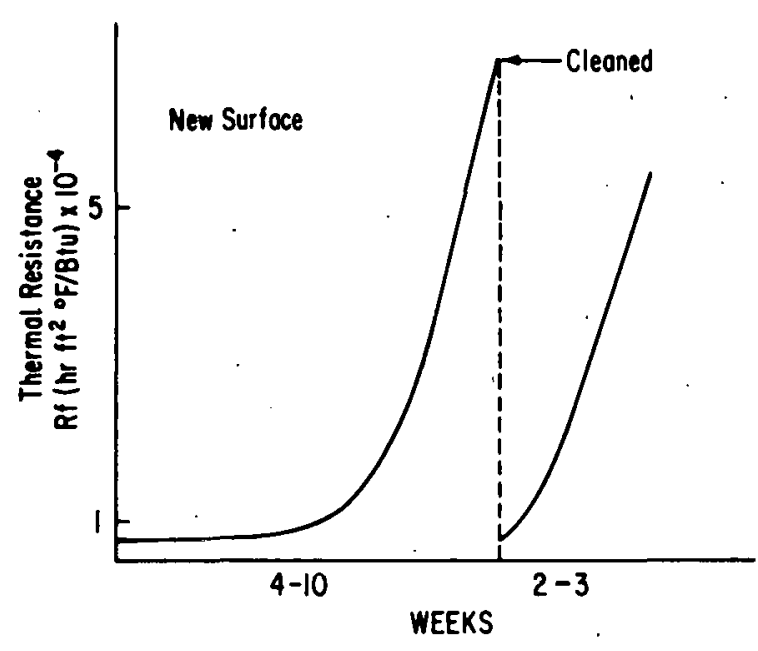

Fig. 2. Diagrammatic Thermal Resistance Curves Observed during Cleaning Tests

environment and on the metal surface.

Field studies of biofilm formation on potential OTEC heat-exchanger surfaces have been undertaken in the Gulf of Mexico,* off Hawaii, ** and off St. Croix. $t$ The process leading to increased heat-transfer resistance is similar in all locations and on all metal surfaces. Heat transfer is not affected for some weeks after immersion in seawater. When resistance begins to develop, however, it grows rapidly. Following cleaning, the lag phase is shortened, or in some cases totally eliminated, and resistance to heat transfer increases immediately. The pattern is shown in Fig. 2. The slope of the growth curve and the delay before onset of fouling depend on the The effect of these variables on micro"Environmental" section of this report.

The events leading to heat-transfer resistance on OTEC heat-exchanger surfaces are only partially understood at this time. Data from the Gulf of Mexico suggest that the microbes attach to the metal surface and undergo some growth during the long initial phase when heat transfer is unaffected. Heat transfer is impeded when the film of living organisms and enmeshed debris reaches a critical size. At this time, the bacteria may not be growing optimally. It appears that, during the phase of rapidly increasing heat-transfer resistance, the microbes are producing copious amounts of polymeric deposits or slime. This slime is probably responsible for the decrease in heat transfer. The initial bacterial layer apparently is very resistant to cleaning. Data from the OTEC fouling-countermeasures program ${ }^{\dagger}$ have shown that microfouling returns rapidly following either chemical or mechanical cleaning of the heat-transfer surface.

\footnotetext{
*Little, B. and D. Lavoie, 1979. Gulf of Mexico Ocean Thermal Energy Conversion (OTEC) Biofouling and Corrosion Experiment in Proceedings of the Ocean Thermal Energy Conversion (OTEC) Biofouling, Corrosion, \& Materials Workshop, 60-100.

**Berger, L. R., W. F. McCoy, and J. A. Berger, 1979. Biofouling Assay for OTEC Pipes, in Proceedings of the Ocean Thermal Energy Conversion (OTEC) Biofouling, Corrosion, \& Materials Workshop, 38-55.

†Aftring, R. P., D. C. Capone, L. Duguay, J. Fell, I. M. Master, and B. F. Taylor, 1978. Biofouling and Site Characterization Studies in the Ocean Thermal Energy Conversion (OTEC) Experiment at St. Croix, U. S. Virgin Islands, in Proceedings of the Fifth Ocean Thermal Energy Conversion Conference, pp. 45-72, Vol. 4 (VIII-X).

††Braswell, J. A., D. F. Lott, and S. M. Hedlicka, 1979. Preliminary Evaluation of Flow-driven Brushes for Removal of Soft Biofouling from Heat Exchanger Tubes in OTEC Power Plants, in Proceedings of the Ocean Thermal Energy Conversion (OTEC) Biofouling, Corrosion, \& Materials Workshop, 149-162.
} 
We know very little about the biochemical events involved in microfouling. Research is needed to explain the relationship between exponential growth in heat-transfer resistance and polymer formation by the microbes. Thermal resistance may be related to biofilm thickness, to film density, or to the accumulation of specific polymers. Research by White and his co-workers* is beginning to provide information about these. A simple relationship, however, has been detected between heat-transfer resistance and total organic carbon (TOC). The TOC assay provides a simple, easily reproducible measure of biofilm accumulation that $c$ an be used to check thermal-resistance measurements.

White is also developing an assay for the film remaining after cleaning. This resistant layer must be understood if we are to develop adequate control measures.

\section{Microfouling and Scale Formation}

The deposition of inorganic scales on OTEC heat-exchanger surfaces may also be a problem. Magnesium and calcium salts accumulate on titanium and stainless steel surfaces; hydrated aluminum oxides appear to accumulate on aluminum tubes.**. A cupric-hydroxychloride overlayer develops on coppernickel tube surfaces that have corroded and formed an adherent cuprous oxide corrosion product. ${ }^{\dagger}$ We know virtually nothing about the interaction between inorganic scale and the organic biofilm on marine surfaces. The microbes may act as precipitation nuclei for scale formation. Significant quantities of inorganic scale materials are found in biofilms on OTEC surfaces. Nucleation could also occur directly, through calcium carbonate secreting organisms, or indirectly in highly supersaturated microenvironments resulting from organic deposition and decay. However, biogenic coatings on the metal surfaces could also have the opposite effect by creating a barrier between seawater and the metal heat-exchanger surface. ${ }^{\dagger \dagger}$

\section{E. Fouling and Corrosion}

The relationship between fouling and corrosion of OTEC materials in contact with seawater cannot be ignored. Attachment and growth of marine organisms influence the rate of corrosion of a number of metals in seawater. Deficiencies in oxygen supply within.crevices and under discontinuous deposits are responsible for initiation of accelerated corrosion. Where the metals involved depend on oxygen-induced passivity for their corrosion resistance,

*Bobbie, R. J. et al. Measurement of Microfouling Mass and Community Structure During Succession in OTEC Simulators--A Preliminary Report, in Proceedings of the Ocean Thermal Energy Conversion (OTEC) Biofouling, Corrosion, \& Materials Workshop, 101-120.

**Morse, J. W. et al. Investigation of the Chemistry of Calcium Carbonate Scale Nucleation and Growth from Seawater on OTEC Heat Exchangers. ANL/OTEC-BCM-006, 1979.

TEfird, K. D. Inter-Relation of Corrosion and Fouling for Metals in Seawater. Materials Performance, April 1976. HMiller, J. D. A. Microbial Aspects of Metallurgy, Elservier, N.Y. (1970). 
localized attack caused by differential aeration is propagated by powerful galvanic cells involving large differences in potential between active and passive surfaces.* Such corrosion cells can be set up by macrofouling organisms, barnacles, for example, attached to stainless steel surfaces. The microorganisms beneath the macrofouling layer also appear to stimulate general corrosion of the metal. Hydrogen sulfide is produced by decaying organisms, stimulating general corrosion.

This phenomenon of accelerated corrosion has also been observed with copper-nickel alloys in polluted waters. Accelerated pitting of $90 / 10$ coppernickel piping has been observed in seawater-handling systems of a $U$. S. Navy ship.** The regions attacked generally displayed films that differed in appearance from the normal dark-brown cuprous oxide film. The description of these films suggests that they were composed of microbes. Evidence indicated that the accelerated corrosion was a result of interaction with putrid seawater containing marine microbes growing in anoxic water. Under these conditions, large quantities of hydrogen sulfide are produced. Pitting of the copper-nickel alloy was correlated with the production of the hydrogen sulfide.

Heavy growth of marine organisms can also act to reduce corrosion by providing barriers to the diffusion of oxygen to the metal surfaces. The controlling effect of oxygen availability through heavy layers of marine growth, common to a variety of compositions of steel, accounts for the observation that ine cuñuposition of steel has little effect on rates of corrosion observed under such exposure conditions. ${ }^{\dagger}$ In addition to effects on corrosion, as a barrier to oxygen diffusion, marine fouling can reduce erosion/corrosion from high-velocity water. Even though the water may be flowing over attached marine growth at a high velocity, the velocity at the interface with the metal below the fouling is practically zero.

The corrosion-product film formed on aluminum alloys probably influences the buildup of microfouling. Conversely, the microfouling almost certainly affects the sloughing off of corrosion products. An understanding of the close relationships between both macro- and microfouling and corrosion processes is needed in the OTEC program. Choice of material, optimization of the heat-exchanger cleaning program, and development of protective measures against macrofouling all require optimization to minimize both fouling and corrosion.

*Miller, J. D. A. Microbial Aspects of Metallurgy. Elservier, N.Y. (1970).

**Gudas, J. P., G. J. Danek, and R. B. Niederberger. Corrosion (1976).

†LaQue, F. Marine Corrosion, Wiley \& Sons, New York (1975). 


\section{THE SEQUENCE OF EVENTS IN MACROFOULING}

Macrofouling of OTEC auxiliary equipment such as pumps, piping, valves, and screens causes clogging of pipes, jamming of valves, and blockage of screens, particularly during intermittent operation. Macrofouling cannot be totally eliminated. The success of control measures is measured by the capability of limiting biofouling accumulation to levels that can be operationally tolerated. The amount of biofouling accumulation that can be tolerated in OTEC systems varies considerably.* Thus the requirements and techniques for macrofouling control will vary among OTEC subsystems. Control of macrofouling in the OTEC program must be based on the state of the art. Both cost and time preclude the possibility of developing new antifouling measures specifically for the OTEC program. Rather, the experience developed in conventional systems exposed to macrofouling organisms must be adapted to unique OTEC plant operations and requirements. The control of macrofouling depends on a knowledge of the organisms growing on the material surface and of the processes controlling attachment of those organisms.

Marine macrofouling is the result of the attachment of larvae of invertebrates and the spores of marine algae settling and growing on submerged surfaces.* The fouling organisms vary from place to place and with different seasons. Different locations in a given area can experience different kinds of fouling. The organisms in a bay causing fouling can vary from those at a nearby shore location. The kind and amount of fouling that does occur depends on the larvae and spores present in the water.

The sequence of fouling organisms that colonize a surface introduced into seawater usually follows a predictable and directional pattern. Each successional stage can be identified by a particular organism or group of organisms, which dominates both spatially and temporally. ${ }^{t}$. It has been shown that not only is fouling controlled by the organisms that are most abundant in the water, but it also depends upon the organisms broadcasting larvae and. a wide range of environmental conditions. The sequence of fouling populations developing on a surface is shown in Table 2. The surface is initially covered

TARLE 2. Development of the Fouling Comminity ${ }^{\dagger}$

\begin{tabular}{|c|c|c|c|}
\hline \multirow[t]{2}{*}{ A. } & Slime-forming organisms & \multirow[t]{2}{*}{ D. } & Secondary fouling organisms \\
\hline & $\begin{array}{l}\text { bacteria } \\
\text { diatoms } \\
\text { protozon } \\
\text { microalgae }\end{array}$ & & $\begin{array}{l}\text { mussels } \\
\text { ascidians } \\
\text { sponges } \\
\text { anemones }\end{array}$ \\
\hline \multirow[t]{2}{*}{ B . } & Prel iminary fouling organisms & \multirow[t]{4}{*}{ E. } & Adventitious organisms \\
\hline & $\begin{array}{l}\text { iydroids } \\
\text { epiphytic algae }\end{array}$ & & $\begin{array}{l}\text { polychaetes } \\
\text { nudibranchs } \\
\text { amphipods and }\end{array}$ \\
\hline \multirow[t]{2}{*}{ C. } & Primary foul ing organisms & & other small crustaceans \\
\hline & $\begin{array}{l}\text { polyzoa } \\
\text { serpulids } \\
\text { barnacles }\end{array}$ & & $\cdot \quad$. \\
\hline
\end{tabular}

*Jenkins, J. F. Corrosion and Biofouling of OTEC System Surfaces/Design Factors Irga Report \#R868, 1978.

**Methods of Controlling Marine Fouling in Seawater Desalination, Dow Chemical Co., Contract \#14302829

OSW Report, 1973.

†Young, L. Y. The Ecology of Bacterial Populations on Surfaces in Seawater. Ph.D. Thesis, Harvard University, 1972. 
by a slime layer. Nutrients from the seawater become bound into the slime biomass, and a selection shift to larger organisms, which can retain their own nutrient storage and have complex life histories, occurs. Once the larvae of these larger organisms are attached, they can survive oscillating nutrient levels and seasonal changes. In other words, later stages have a stronger capacity for competitive survival.

The possibility that macrofouling can be controlled by preventing the initial slime layer from forming has been investigated in recent years in a number of different laboratories. A bacterial slime layer is always detectable on surfaces exposed to the larvae of fouling animals. It has been inferred that the mucilaginous surface has general adhesive properties, which promote the attachment of both algal spores and animal larvae. However, close observation of larval settling behavior has shown that settlement onto a surface is a very complex process. Laboratory studies indicate that macrofouling organisms settle and grow better on surfaces containing microbial slime. However, other factors, including chemicals produced by seaweeds and by other fouling organisms, may be equally important.

Although slimes promote macrofouling, it may not be controlled by preventing bacterial slime formation. Even on cleaned OTEC heat-exchanger surfaces sufficient bacteria are probably present to stimulate larval settlement. The development of control measures must be based on the assumption that the fouling community present in the sea can attach to ajll surfaces in contact with seawater under the appropriate environmental conditions. For example, intermittent chlorination limits microfouling. Macrofouling larvae, however, continue to settle between chlorination periods. The development of appropriate countermeasures will depend on information about the fouling organisms present at a potential OTEC site and a description of the fouling rates at different times of the year. A wide range of conventional antifouling procedures are available and are recommended for use in the OTEC program. These countermeasures are discussed in a later section of this report. 


\section{ASSESSMENT OF MICROFOULING}

Very thin biofilms retard heat transfer on potential OTEC heat-exchanger surfaces. Methods have been developed to measure this effect directly using the overall heat-transfer coefficient. These heat-transfer devices integrate the effect of thin films on thermal resistance without revealing anything about the nature of the film, or the kinetics of biofilm formation. Biochemical methods are available and are being developed to assess the biological processes occurring during biofilm formation. In addition, nondestructive assay techniques are available and might yield better insight into the nature of biofilms. The techniques available for assessment of microfouling in the OTEC program are discussed below.

\section{A. Heat-transfer Monitoring Devices (HTMs)}

An accurate method of measuring thermal resistance caused by very thin biofilms has been developed for the OTEC program by Fetkovich and his coworkers at Carnegie-Mellon University. Heat-transfer rates are monitored in heat-exchanger pipes with a precision of $1 \%$ or better.* This CMU device involves a heat-exchanger pipe with seawater flowing through. it. The apparatus has two thick-walled sections made of copper cylinders. One section is surrounded by a Nichrome heater. The other section is a reference block that is used to measure ambient temperature. The first section is heated, and the temperature difference between it and the reference block is measured using a thermopile composed of a set of thermocouples. The thermopile sensitivity of measurement of temperature difference is $0.001^{\circ} \mathrm{F}$. When 124 watts are applied in the heater windings the temperature at the thermocouple increases $2.1^{\circ} \mathrm{F}$ above water flowing at $6.0 \mathrm{ft} / \mathrm{sec}$. The heater is turned off, and the temperature returns to ambient.

The temperature-decay curves in the CMU device are highly linear. Voltage output from the thermopile is assumed to vary linearly with temperature difference. The heat-transfer coefficient is measured with a precision of better than $1 \%$. The CMU method is accurate for measuring loss of heat transfer resulting from thin biofilm formed on the heat-exchanger tube surface. In the field the error rises to $2 \%$ because of fluctuations in water temperature. In tests off Hawaii, Fetkovich demonstrated the dependability of the apparatus in measuring thermal resistance ( $R f$ ) of thin biofilms. He compared Rf values as a function of time using different metals and flow velocities. The data appeared to be both accurate and reproducible as a means of assessing microfouling.

Use of the Carnegie-Mellon device in other locations has shown that it is a rugged apparatus, yielding acccurate data. Experiments in 1977 off St. Croix

*Fetkovich, J. G., et al. Studies of Biofouling in Ocean Thermal Energy Conversion Plants in Fourth OTEC Conference, New Orleans, 1977. 
confirmed the data obtained in the Pacific off Hawaii relating thermal resistance to biofilm accumulation on the inner wall of heat-exchanger pipes. However, since the CMU device was designed for pipe rather than tubing, which is representative of actual heat-exchanger conditions, the device was redesigned to accept tubing and improved to facilitate sample replacement.*

\section{B. Biological Measurements}

Three methods are routinely used to analyze the biofilms developing on OTEC heat-exchanger surfaces. They are scanning electron microscopy (SEM), adenosine triphosphate (ATP), and total organic carbon (TOC). In addition, other biochemical analyses are being developed to provide more detailed information about the nature of the biofilms.t The applicability of each of the tests being used routinely in the program is discussed below.

Typically, biofilms formed on OTEC surfaces are very thin and contain very small quantities of biomass. Therefore, minor sampling variations may result in wide fluctuation in reported data. It is necessary in the OTEC program to develop standardized sampling procedures and analytical techniques for microfouling studies if the data provided by different investigators working at widely different geographic locations are to be compared. A sampling and analytic protocol has been designed specifically for OTEC studies in the Gulf of Mexico. The sampling system was designed by B. Little at NORDA at Bay St. Louis, Mississippi, and has been field-tested thoroughly at sea. $\dagger$ Methods are described for removing pipe sections to be sampled without loss of the seawater from the pipe. The use of sample coupons for SEM is also described. The protocol provides standard methods for fixation of samples for SEM, ATP, and TOC measurement. This protocol has been adopted for use off Hawaii and Puerto Rico. The continued use of standardized sampling and analytical procedures will facilitate data interpretation in the microfouling program.

SEM provides a qualitative and semiquantitative measure of the attachment and growth of microbes on the surface in contact with seawater. It allows estimation of film thickness, provides information on the type of organisms attaching to the surface, and shows, whether the organisms are being trapped in polymeric matrices or are growing on the surface. SEM studies are particularly useful when combined with biochemical analyses.

ATP is present in all living organisms. It is therefore used routinely to quantitatively analyze for the presence of microbes on fouled pipe sections.

\footnotetext{
*Gavin, A. P., M. Rodin, and G. F. Popper, 1979. A Module for Measuring Rf and Collecting Biological and Corrosion Specimens. Proceedings of the Ocean Thermal Energy Conversion (OTEC) Biofouling, Corrosion and Materials Workshop, Rosslyn, VA. ANL/OTEC-BCM-002.

**White, D., R. J. Bobbie, and P. H. Benson, 1980. Biochemical Analysis of the Response of the Marine Microfouling Community Structure to Cleaning Procedures Designed to Maintain Heat Transfer Efficiency. Proc. 5th Int'l. Congress on Marine Corrosion and Fouling, Barcelona, 1980.

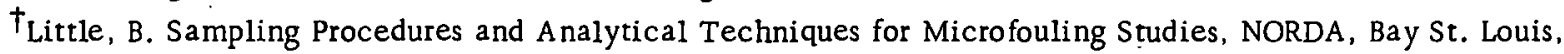
Mississippi, 1978.
} 
However, ATP assays are only accurate in a narrow range of film thickness. During initial attachment of bacteria, the quantities of ATP produced are too small to be detected, and when film thickness becomes large, the organisms on the inside of the film are dead and therefore cannot be measured using the ATP method. In addition, ATP does not measure the large quantities of polymeric material produced by the bacteria.

TOC correlates very well with $\mathrm{Rf}^{*}$ * This method provides a measure of both living bacteria and bacterial polymers accumulating on the surface. It is therefore insensitive to the presence of either dead bacteria or to the accumulation of polymers at the expense of bacteria. Since thermal resistance is caused by the total biofilm rather than by the bacteria alone, TOC provides a simple means of assessing the contribution of biofilms to thermal resistance. Berger has also shown that total nitrogen and protein in OTEC tube samples can be correlated to the fouling resistance (Rf). This correlation suggests either that biofouling is caused by the bacteria growing on the surface or that their polymeric exudates are proteinaceous in nature. More detailed biochemical studies are needed to explain this correlation.

White is developing more sophisticated techniques for the assay of microbial biomass, population structure, and polymer production in the OTEC microfouling program.** The ATP method of analyzing for microbial slimes is inaccurate, particularly with the small quantities available in OTEC samples. White has developed a modification involving analysis of all three adenine nucleotides produced by bacteria. Using high-pressure liquid chromatography, he can recover $92 \%$ of the nucleotides in biofilm on OTEC samples. This allows him to accurately measure the very early stages of biofilm formation.

In addition, he used a combination gas chromatograph and fast-scanning quadruple mass spectrometer to detect fatty acid methyl esters in the biofilm. This allows him to accurately define the population structure of the bacteria in the film. The method allows reproducible analysis of the bacterial population on different materials, at different geographic locations, or in different cleaning cycles.

White has developed sensitive and quantitative assays for the polymers produced by the microbes on OTEC surfaces. He can assay for amino sugars, muramic acids that are present in bacteria, and extracellular polymers produced by the microbes on the surface. Analysis of these polymers will provide information about the process causing thermal resistance. In addition, it is important to be able to biochemically analyze these biofilms in order to determine the nature of plaque films accumulated during cleaning cycles.

* Bérger, L. R., W. McCoy, and J. Berger. Proceedings Annual OTEC Conference, 1979.

**White, D. Proc. Sixth OTEC Conference, 1979. 


\section{Nondestructive Assays}

The development of microbial biofilms can be measured directly and nondestructively. Some of these methods, discussed below, are being tested for application in the OTEC program. Nondestructive assays would permit continuous measurement of slime formation in parallel with thermal resistance, permitting the assessment of both organic film accumulation and the efficiency of countermeasures in the removal of microbes and their products.

The first stage of microfouling involves the accumulation of polymers from the water column. If this film could be prevented from forming, microfouling would probably be inhibited. It is also probable that this polymeric film is not completely removed by cleaning and accumulates with each cleaning cycle. Baier has developed methods allowing the direct characterization of adsorbed films on surfaces using internal-reflection infrared spectroscopy. This method provides characterization of the molecular groups present in the adsorbed film. He uses ellipsometry to determine the thickness of the adsorbed film. Surface potential is used to find the strength of the film; wettability measurements yielded the atomic constitution of the chemical groups exposed on the films. These measurements can be carried out without disturbing or damaging the surface.* This method would provide important information for the OTEC program. It could answer the question of the differences of rates of microfouling accumulation on different surfaces and at different. locations. It may also provide a useful tool to determine the nature of accumulated films in the countermeasures program.

Frictional resistance increases due to biofilms until the thickness exceeds the viscous sublayer. A biofilm thickness of $35 \mu \mathrm{m}$ has no effect upon the system's friction factor. Above $40 \mu \mathrm{m}$, the biofilm creates unexpectedly high increases in frictional resistance. Measurement of frictional resistance has been shown to parallel heat-transfer resistance, biofilm thickness, and biofilm mass.** This method provides a simple direct laboratory measure of biofilm formation without destroying the sample. The method appears to be sensitive and precise. It has not been tested under OTEC conditions; however it may provide a reliable and sensitive indicator of the later stages of biofilm development. If measurements parallel Rf and total organic carbon, it could provide a simple nondestructive check on thermal resistance.

Ultrasonic methods may also be used to detect, measure, and characterize slime films. The amplitude of the echo from the slime-water interface should provide a measure of the film thickness. The attenuation of ultrasonic signals may also provide some information about the structure of the film. The feasibility of this nondestructive method of following the kinetics of biofilm formation is currently being tested by the New York Institute of Technology. It provides for the possibility of placing tiny transducers on the surfaces of heat exchangers, allowing continuous monitoring of biofilm formation.

*DePalma, V. and R. Baier. Proc. OTEC Biofouling and Corrosion Symp. Seattle, 1978.

**Bryers, J. D. and W. G. Characklis. Proceedings Condenser Biofouling Control Symposium, Atlanta, 1979. 


\section{MACROFOULING ASSESSMENT}

Al1 unprotected structures in contact with the sea will foul. The rate of accumulation is mainly dependent on the nutrient status and temperature of the water. The predominant open-ocean fouling organisms are hydroids that are present from the surface to the bottom in decreasing numbers, barnacles present to about $4000 \mathrm{ft}$, mussels down to about $100 \mathrm{ft}$, and tunicates present in warm water to about $500 \mathrm{ft}$. In addition, there is usually growth of the filamentous algae in the photic zone. Most hard-shelled forms of macrofouling are usually also found only in the photic zone. Marine borers are found at all depths. Organisms capable of boring into lead, concrete, plastic, and wood are all normally present in open ocean waters.

Macrofouling rates are normally determined by exposing standard 5-cm by $30-\mathrm{cm}$ wood or asbestos test panels at stations in the water. The term "fouling rate" is defined as the dry weight of attached organisms per unit area.of substrate per unit of exposure. This dry-weight value provides a quantitative measure of fouling productivity. Panels are usually recovered monthly. until fouling becomes maximal. Typically exposure times are one to two years. The dry-weight values for a series of exposures are often plotted on a crosssectional chart of the test area and contoured by percent of maximum accumulation using the highest value, the shoreline station, as $100 \%$. These data provide predictive forecasts of fouling rates for stationary structures at specific locations.

In addition to weight measurements, panels are routinely observed for abundance of specific macrofouling organisms. Since control measures depend on the organisms present on the surface, it is important to determine the species abundance in each situation. There are at least. 2000 different species of organisms that are recorded as a marine-fouling nuisance of some degree. However, only 10 groups of macrofouling organisms are usually categorized as a major nuisance. These are described briefly below.

\section{A. Barnacles}

Barnacles are distributed worldwide and are the most common fouling organism. They colonize surfaces at all ncean depths. Acorn barnacles attach directly to a surface. Gooseneck barnacles have a long attaching stalk and are usually found on floating debris. Gooseneck barnacles do not adhere. to a substrate as firmly as acorn barnacles and are more easily removed.

The most common fouling barnacles are of the genus Balanus. The larvae of these barnacles are retained within the shell of the parent and are discharged as free-swimming nauplii. Eventually a cyprid larva is formed. The cyprid seeks a suitable substrate and eventually settles permanently. The barnacle attaches to the substrate by means of a cement that holds the animal firmly to the surface. Experiments have shown that larvae that have settled produce cement, attaching them permanently to the surface within 18 minutes 
after contact. After settlement, the cyprid larva molts to yield a juvenile barnacle within 20 hours. It is therefore important in any countermeasures program to provide continuous treatment so as to prevent settlement of the larvae.

\section{B. Mussels}

In the absence of control treatment, hundreds of tons of mussels will accumulate in the seawater intake system of power plants. These bivalves are normally found in temperate waters all over the world. Mussels attach themselves to surfaces by byssal threads. The threads are made of a tanned protein similar in structure to barnacle cement.

Mussels have a free-swimming larval stage and juvenile stage when the - animal attaches to a substrate. Young mussels may often move about on a surface before settling. The shell is composed of tanned protein and calcium carbonate. The shell $c$ an be closed when the environment becomes unfavorable, for example, when toxic chemicals are applied. In addition, the byssal threads attach the organism firmly to the substrate so that mussels can resist physical cleaning methods.

\section{Sponges}

Sponges can be identified as an amorphous mass of various colors with a slimy covering. The sponge is often one of the first organisms to colonize a surface in warm waters and is usually found in combination with other fouling forms such as bryozoans or tunicates. Those sponges that cause fouling have a basic supporting structure known as a spicule, made of silica. Masses of spicules form a skeleton for the sponge to attach to the substrate.

\section{Sea Anemones and Hydroids}

These two organisms belong to the coelenterate group. They are a11 characterized by the production of stinging cells called nematocysts. The fouling forms all have polyps, tube-like animals with an opening at the top. There may be as many as 1000 polyps in a hydroid colony. These organisms, unlike hard foulers, can move. When the environment becomes unfavorable, they frequently detach their pedal disc at the base of the colony and float to another site, where they will attach to a new substrate. Thus, fouling-control methods against adults are usually unsuccessful. As with other forms of fouling, control depends on preventing larval attachment rather than removing adult forms. The hard corals, which are also members of the coelenterate group, are anticipated to be a major problem at tropical OTEC sites.

\section{E: Bryozoans,}

Bryozoans are another form of colonial animal. The colonies resemble red or brown algae, sponges, hydroids, and even tunicates. The colony 
consists of a gelatinous or calcarious box-like set of compartments arranged in patterns that are characteristic of the species. Each compartment contains an individual animal. Fouling forms of bryozoans metamorphose and grow over the surface or grow upright like a plant. Bugula is a common upright bryozoan and normally appears as a brushy growth made up of branches in double rows. The color is usually straw or red. Bryozoan larvae settle collectively on substrates. However, the chemical cues for surface selection are unknown.

F. Serpulids

Serpulids are tube worms. They live in white calcarious tubules that are an inch or more in length. They grow in such masses that they can cover a large surface and because of the rapid growth, are often the first fouling organisms found on the surface. Many of these organisms are filter feeders. Eggs of the tube worms are liberated into the water and the larva develops into a free-swimming member. This free-swimming form settles on the substrate, secretes a tube, and undergoes metamorphosis into an adult worm.

The larvae are $4 \mathrm{~mm}$ long. They visit a large number of substrates, and when a favorable one is found, they select a site and attach. A milky fluid is secreted from an attachment gland forming the initial tube: This process from initial fixation to the formation of the tube takes one to two minutes. Once again, we see an example that control of larval attachment is essential if macrofouling is to be prevented. Once the larvae are attached, removal becomes very difficult.

\section{G. Tunicates}

Tunicates are members of a group of organisms that have backbones, so are closer to free-swimming fish than they are to the shellfish. The larval form is tadpole-like and has a primitive backbone. The adult forms are soft sacklike creatures that either grow singly or in colonies. The simple tunicates have two body openings called syphons. A stream of water is drawn in the one syphon' and expelled through the other: The simple tunicates can be recognized by their production of jets of water when they are taken out of the sea, giving them the name sea squirts. These fouling organisms are covered by a protective layer or tunic of tough cellulosic material. The colonial forms can be recognized by their appearance in large brightly colored groups on marine surfaces. They may be purple, orange, or yellow.

\section{H. Amphipods}

This group of crustaceans is an important component of the fouling community. Fouling amphipods are relatively small and are rarely more than $10 \mathrm{~mm}$ long. They resemble small shrimp and often produce tubes. Ultimately, large masses of these tubes can cover a surface. 
I. Algae

In the photic zone, the algae are usually among the first organisms to colonize a surface. Slimes of algal sporelings form within a week or two. Eventually, filamentous forms grow on the surface and are often a major source of fouling. Both the sea lettuce, Ulva, and the complex branched green alga, Enteromorpha, are commonly found on fouled surfaces.

J. Stone-boring Mollusks

Borers into rocky substrates can be expected to attack OTEC materials. Some marine borers can attack plastic and lead sheathing in addition to rocks. The most successful and highly adapted stone borers, the pholads, are bivalve mollusks. The pholads live in all types of stone normally found in the sea. They have shells with sharply serrated edges and use these, possibly in combination with chemical mechanisms, to bore into very hard rock, but not granite.*

The teredine borers Bankia, Lyrodis, and Teredo, as well as the pholad, Martesia, have been shown to attack plastics. The polyvinyl chlorides are most susceptible to severe damage and deep penetration. Martesia has also been observed to attack. PVC, nylon, and some high-density polyethylenes.

*Haderlie, E. C. Marine Borers, A Potential Threat to Concrete and Polymeric Materials in OTEC Systems. Proc. of the OTEC. Biofouling and Corrosion Conf., 1977. 
VI. ENVIRONMENTAL FACTORS AFFECTING FOULING

A'wide range of environmental factors affect the fouling rate and dominance of the organisms present in both microfouling and macrofouling processes. Natural environmental conditions, such as water chemistry and temperature, can only be influenced by choice of location, while other factors including flow velocity, substratum choice, and other design decisions can be adjusted on the basis of the potential fouling hazard. This section considers the more important environmental factors affecting both macro and microfouling.

\section{A. Water Chemistry/Nutrients}

Very little is known about the chemical factors controlling settlement of macrofouling organisms. The presence or absence of larvae is controlled by a wide range of environmental factors. Predictions about the presence of specific. fouling organisms or their rate of attachment and growth are not normally related to the nutritional status of the water.

In contrast, the kinetics of microfouling are closely related to the chemistry of seawater. Nutrient-rich waters usually yield thick biofilms at rapid rates, whereas: nutrient-deficient waters yield very thin biofilms or the rate of initial film formation is very slow. In addition, the attachment of microorganisms to surfaces is closely related to the production of biopolymers by the microbes. In waters that are rich in carbon but deficient in nitrogen, there is a tendency of the microbes to produce large quantities of polymers. These polymers stimulate the attachment of the microbes to the substrata. Thus, with the polymers acting as adhesives, the efficiency of attachment is increased. Even in nutrient-deficient water, these attached microbes, with their thick matrix of polymeric fibrils, concentrate nutrients present in the water. This enriched matrix acts as a trap for other microbes present in the water column, which can attach and grow rapidly as soon as they are embedded in the matrix. Thus, while the chemistry of the water is an important factor in the initial growth of microbial biofilms, biofilm formation is probably independent of the nutrient status of the water at a later stage. After a number of cleaning cycles, the polymeric matrix developed on the metal surface is probably the dominant factor controlling the nutrient status of the microbes, and growth is less dependent on the chemistry of the water column.

\section{B. Temperature}

Temperature is an important environmental factor controlling both the rate of attachment and growth of macrofouling organisms. In warm tropical waters, fouling rates are generally high; in temperate and cold waters, they are usually lower. In addition, temperature influences the species present at a location. Each macrofouling organism has a specific range of and optimal temperature at which it can survive. Although some macrofouling organisms, such as mussels and barnacles, have a very wide temperature range, others, such as specific bryozoans, have narrow temperature ranges. 
Although temperature has a less drastic effect on the specificity of microorganisms growing on OTEC surfaces, it is critical in the control of the rate of microbial growth and biofilm formation. Both the number of microbes attaching to a substratum and the rate of growth are directly related to water temperature. Both the rate of attachment and the growth rate increase at higher temperatures.* This close relationship is observed in the temperature, range between 4 and $30^{\circ} \mathrm{C}$.

\section{Pressure}

The effect of pressure changes on fouling organisms is not well known. In OTEC systems, large quantities of deep water will be brought to the surface. The potential of this water to cause either macrofouling or microfouling is unknown. Although the quantities of macrofouling larvae present in the deep water may be small, there is increasing evidence that many of these larvae will survive transport to the surface and will grow to cause a fouling problem. In particular, clams, mussels, and barnacles may be expected to be present in the cold deep water and to survive movement to the surface.

There is abundant evidence that the rich microbial population found in deep waters and sediments survives transport to surface waters. Slime formation on surfaces exposed to the water brought from the ocean depths will be primarily controlled by the low temperature of the water rather than by the number of microbes in the water.

\section{Water Depth}

There is a direct correiation between fouling rates and water depth. Figure 3 shows that there is a dramatic decrease in the quantity of fouling

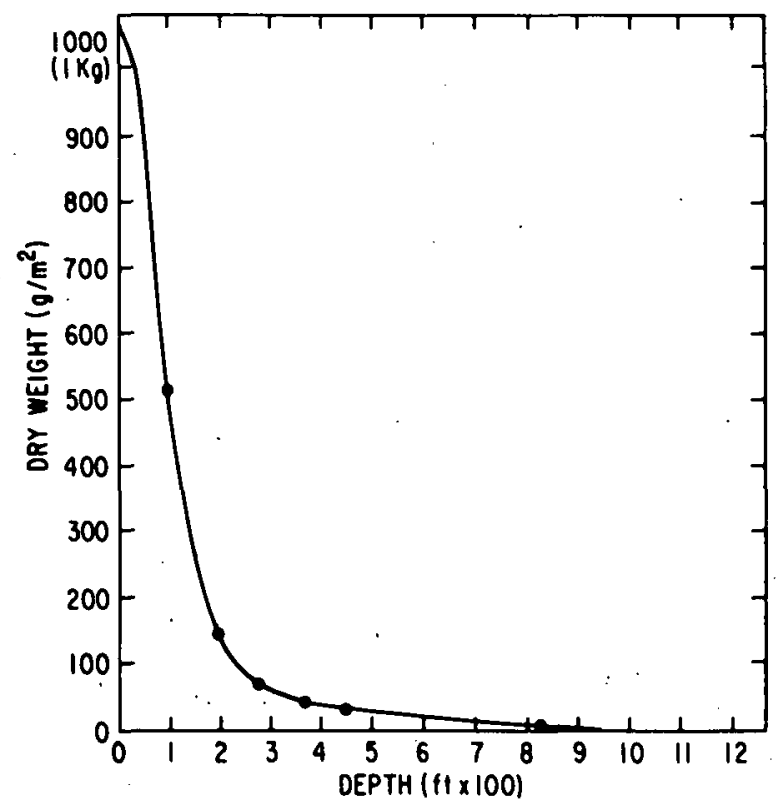

Fig. 3

Biofouling Mass as a Function of Depth in the Tongue of the Ocean. '(Castelli, V.J. Corrosion and Biofouling on the Non-heatexchanger Surfaces of an Ocean Thermal Energy Conversion Power Plant. Report No. DTNSRDC-79/054, p. 28,1979 .)

\footnotetext{
*Young, L. Y. The Ecology of Bacterial Populations on Surfaces in Seawater. Ph.D. Thesis, Harvard University (1972).
} 
below $300 \mathrm{ft}$, until the ocean floor is reached, where it will increase again. At the water surface, structures are usually covered by algae. Below this is a calcareous zone dominated by barnacles. Within this zone and at lower levels, we find tube worms, hydroids; and bryozoa. Table 3 shows a general relationship between depth and geographic location of some fouling organisms. Marine borers are found attached to virtually all surfaces at all depths. These borers attack a wide range of material including wood, lead, concrete, and plastic. The initial macrofouling rate decreases drastically in the open ocean with distance from land. At more than 65 miles off-shore, the fouling rate on surfaces is very low. However, larvae are present, and after an initial colonization period, OTEC structures $c$ an be expected to foul as rapidly as if they were in coastal waters.

TABLE 3. Habitats of Fouling Organisms ${ }^{a}$

\begin{tabular}{|c|c|c|c|}
\hline Organism & & $\begin{array}{l}\text { epth } \\
(f t)\end{array}$ & Range of Ocean \\
\hline Hydroids & Surface & to bottom & All over \\
\hline Gooseneck barnicles & Surface & to $500 \mathrm{ft}$ & Open ocean on $1 y$ \\
\hline Mussels & Surface & to $100 \mathrm{ft}$ & Shore to $30 \mathrm{miles}$ \\
\hline Starfish & Surface & to 8,000 & All over \\
\hline Snails & Surface & to 10,000 & Especially in Pacific \\
\hline Bivalves & Surface & to 14,500 & Especially in Pacific \\
\hline Tubeworms & Surface & to 16,500 & Coastal waters \\
\hline Sea urchin & Surface & to 16,000 & A1l over \\
\hline Sponges & Surface & to 600 & Coastal waters \\
\hline Bryozoans & Surface & to 900 & All over (coastal waters) \\
\hline Tunicates & Surface & to 500 & All over \\
\hline Borers & Surface & to bottom & Al1 over \\
\hline Jellyfish & Surface & to bottom & All over \\
\hline Fung $i^{-}$ & Surface & to 600 & All over \\
\hline Acorn barnacle & Surface & to 500 & Coastal waters (all over) \\
\hline
\end{tabular}

after Castelli, V. J. Corrosion and Biofouling on the Non-heatexchanger Surfaces of an Ocean Thermal Energy Conversion Power Plant. Report No. DTNSRDC-79/054; p. 30, 1979.

DePalma has shown that in warm seas, substrates completely covered by hardshelled organisms can weigh about $17 \mathrm{~kg} / \mathrm{m}^{2}\left(1.71 \mathrm{~b} / \mathrm{ft}^{2}\right)$ in water. However, once the surface is completely covered, there is little or any additional weight increase with time.* When the dimensions of an OTEC plant are determined, weight from accumulated hard-shell foulers can be calculated and, if need be, reserve buoyance can be incorporated into the design. DePalma believes that soft-bodied foulers contribute little significant weight in water and that weight gained due to macrofouling is not a factor in OTEC design.

\section{E. Water Velocity}

The settlement of invertebrate larvae is related to the flow velocity. Although the critical velocity which will prevent attachment of larvae within

\footnotetext{
*DePalma. Proc. OTEC Biofouling and Corrosion Conf., 1977.
} 
piping systems is not well defined, it probably.lies within a 2-4-ft/sec range.* When the surface is rough, a velocity of 4-6 ft/ sec may be required. The velocity must be maintained and must exist at a distance of not more than $0.5 \mathrm{~mm}$ from the wall, since many of the fouling larvae are as small as $0.5 \mathrm{~mm}$ wide. The use of velocity to control macrofouling is not recommended. Flow interruption, even for very short periods, always results in the settling of fouling larvae, which once attached are not dislodged when flow is resumed. Fouling downstream of obstructions, such as screens and other obstacles, normally occurs even in systems where the flow velocity is continuously rapid. In addition, high water velocities in excess of $6 \mathrm{ft} / \mathrm{sec}$ are unlikely to be maintained in regions of turbulence or reduced flow, such as water boxes, at tube sheets, or throughout much of the seawater piping system.

Water velocity is probably an important factor controlling the rate of microfouling.** However, the relationship is complex, involving the adsorption of nutrients onto the substratum, thus controlling the growth of the biofilm. Other factors are involved, including the nature of the microbe attached to the surface, the nature of the nutrients absorbing to the surface, and temperature. Since these factors are continuously changing in natural seawater, the effect of flow rate on biofilm growth cannot be predicted. It is therefore not recommended that biofilm formation be controlled by adjustment of flow rate.

\section{F. Material Surfaces}

There is considerable controversy in the literature about the effect of materials on either macrofouling or microfouling rates in seawater. Except for inherently toxic surfaces such as copper, there is no evidence that macrofouling occurs more rapidly on one surface than another. By the time the macrofouling larvae approach a surface in the sea, it is probably completely coated with microbes so that the nature of the surface becomes irrelevant.

The formation of biofilms does appear to be affected by material surface. Large numbers of bacteria have been observed to attach to hydrophobic plastic with little or no surface charge, including tefion, polyethylene, and polystyrene. ${ }^{\dagger}$ Much smaller populations of microbes attach to hydrophilic metals with positive charge, such as platinum or germanium. Extremely few bacteria were found to attach to hydrophilic negatively charged substrata such as glass, mica, or oxidized plastics. Dexter has suggested that both the thermodynamics and interfaces involved in the attachment of microbes to surfaces are extremely complex. ${ }^{\dagger \dagger}$ He suggests that the attachment of bacteria to surfaces in aqueous media depends on both critical surface tension of wetting and on the absorption of molecular organic conditioning films to the solid surface. Predicting the influence of substratum on microbial biofilm formation will be difficult until we understand more about these complex interactions.

\footnotetext{
*Jenkins, J. F. Corrosion and Biofouling of OTEC System Surfaces-Design Factors, ERDA Report R868 (1978).

**Wuhrmann, K., 1974. In: Water Pollution Microbiology, Vol. 1, R. Mitchell, Ed., Wiley \& Sons, New York.

†Fletcher, M., and G. 1. Loeb. Applied and Environmental Microbiology, Vol. 37, p. 67, 1979.

${ }^{\dagger}$ Dexter, S. Journal of Colloid and Interface Science, Vol. 70, p. 346, 1978.
} 
G. Mechanical Design

Mechanical-design factors will have an important effect on the attachment and growth of both microfouling and macrofouling organisms. These factors include geometry, orientation, layout, surface finish, cathodic protection, antifouling coatings, and cleaning systems. They must be considered both individually and as an integrated system.* The most obvious effect of geometry is light. Macrofouling organisms are sensitive to light and often are attracted to low-1ight-intensity surfaces. However, macrofouling occurs at all light intensities, so that light cannot be used to retard fouling. An exception is the control of algae. These organisms are photosynthetic and therefore will fail to grow on surfaces maintained in the dark.

Geometry has 1 ittle effect on microfouling of heat-transfer surfaces. However, geometry will indirectly affect these surfaces by influencing other factors such as velocity and turbulence. Of greater importance is the effect of geometry on cleaning. Heat-transfer surfaces designed so as to enhance the surface without allowing for adequate cleaning of the enhanced area will present a serious problem. Orientation of the surfaces can also be important, for both macrofouling and microfouling organisms. In general, for experimental purposes it is recommended that the surfaces be maintained vertical so as to minimize these differential effects and facilitate sample removal.**

Surface finish has been shown to be imporțant in initial fouling. Polished surfaces are initially more resistant to both macrofouling and microfouling than rough surfaces; however, this effect is rapidly overcome as the surfaces become enriched with slime. Surface finish is of particular importance in metals. The highly corrodible metals, such as steel, foul easily. The fouling layer, however, is easily removed with the typically loose corrosion product. Passive metals, such as stainless steel or titanium, also foul easily, but the fouling, is removed less readily. Copper alloys exhibit antifouling characteristics. Their fouling resistance is attributed to a coherent cuprous oxide corrosion product which is toxic to organisms. With time, an overlay of cupric hydroxychloride forms and suppresses this toxicity. However, the fouling that occurs is usually. loosely attached and easily removed. Copper surfaces that are layered with silt or biological debris also quickly lose their resistance to fouling. As soon as microfouling builds up on the copper alloy, macrofouling organisms can attach and the surface may soon become coated with a macrofouling layer. Cathodic protection of copper alloys also suppresses their antifouling properties.

The use of antifouling coatings for control of macrofouling will be considered in our discussion of countermeasures. The equipment in OTEC systems must be designed to allow for adequate dewatering and recoating. This practice is essential because of the short life of antifouling coatings. If coatings cannot be replaced economically, then they are not a practical alternative.

\footnotetext{
* Jenkins, J. F. Corrosion and Biofouling of OTEC System Surfaces-Design Factors, ERDA Report R868 (1978).

**Benson, P. H., 1979. Biology of Fouling: Summary, Proceedings of the Ocean Thermal Energy Conversion (OTEC) Biofouling, Corrosion and Materials Workshop, Rosslyn, VA, ANL/OTEC-BCM-002.
} 


\section{MICROBIOFOULING COUNTERMEASURES}

Fouling of condensers by microbial slime is controlled in conventional power plants by chlorination and/or by mechanical cleaning. OTEC heat exchangers must be maintained at a cleanliness level significantly lower than conventional power-plant condensers. An Rf value of $0.0001-0.0003 \mathrm{hr}-{ }^{\circ} \mathrm{F}-\mathrm{ft}^{2} / \mathrm{Btu}$ has been set as the goal for OTEC heat exchangers. No experience is available from conventional power plants describing appropriate countermeasures to yield this degree of cleanliness. To determine which countermeasures are suitable for OTEC heat exchangers, tests have been undertaken at the Naval Coastal Systems Center, Panama City, FL. In addition, microfouling countermeasures are being assessed at Inco's LaQue Center for Corrosion Technology. The purpose of these initial tests is to evaluate those countermeasures that appear to be most appropriate to the maintenance of OTEC heat exchangers. The laboratories have been chosen because of their location where nutrient-rich coastal waters are available that yield rapid microfouling. Countermeasures that have been qualified under these conditions will be extensively tested for long periods of time in open ocean waters at the Seacoast Test Facility and at other future test sites.

\section{A. Flow-driven Brushes}

The most advanced flow-driven brush system is marketed by the MAN Corporation of West Germany. It consists of plastic baskets permanently fixed to the ends of each heat-exchanger tube. A brush consisting of a titanium core and plastic bristles is shuttled between the baskets by means of seawater flowreversal mechanisms. Experience with seawater-cooled power plants has shown that the success of this method depends strongly on the control of marine macrofouling organisms from the inflow.* The presence of macrofouling organisms either on the catching basket surfaces or on the bristles would impede operation of the MAN system. Major modifications of the mechanical design would probably be required before the MAN system could be used in OTEC heat exchangers .

Preliminary tests using MAN brushes on a cycle of two passes every 8 hours indicate that titanium pipes can be kept clean for 70 days. Under similar conditions, aluminum alloy 5052 pipes could not be maintained at an $\mathrm{Rf}$ of $0.0001 . * *$

Tests in Panama City, FL, showed that the MAN system suffered from serious problems related to macrofouling. Because of the presence of low-velocity areas near the ends of the pipes, substantial macrofouling occurred. These communities directly affected the operation of the brush cages and also contributed to the volume and composition of debris passing through the tubes. Ultimately, the buildup of debris from these communities completely stopped

\footnotetext{
*Rice, M. S., D. Hagel and A. F. Conn. Hydronautics Report No. 7707-1, 1978.

${ }^{* *}$ Kinelski, E. H. The Requirements for Biofouling, Corrosion and Materials in the OTEC Program. Proceedings of the OTEC Biofouling, Corrosion and Materials Workshop, 1979.'
} 
action of the MAN brushes.* In addition to these results, erosion/corrosion occurred on aluminum samples. It may be possible to combine MAN brushes with chlorination to prevent the development of a macrofouling community, while maintaining the heat-exchanger surface free of microfouling. However, considering the problems encountered and associated power losses due to flow reversal, it is not possible at this time to conclude that flow-driven brushes are either appropriate or inappropriate for OTEC use.

\section{B. Amertap Recirculating Rubber Balls}

The Amertap system is applicable to those heat-exchanger designs that have water flowing within smooth, round tubes. It uses sponge-rubber balls, which are injected at the upstream water box and randomly driven by the water into heat-exchanger tubes. The oversized balls wipe the inside tube surfaces. At the downstream water box, the balls are collected by special screens and recirculated to the upstream end of the tube bundle. Due to wear and contamination, the balls need to be counted, sorted, and replaced about once a month. The procedure can be fully automated. There are about 2000 Amertap installations in Europe and about 200 in the United State. The record of success in maintaining condenser efficiency and reliability is excellent. The Amertap Corporation has indicated that their system would provide clean shell and tube heat exchangers for OTEC use. Figure 4 compares Amertap use in a number of locations with different metals compared to the OTEC limit. These data were presented by Amertap personnel to the Department of Energy at a meeting in May 1979.

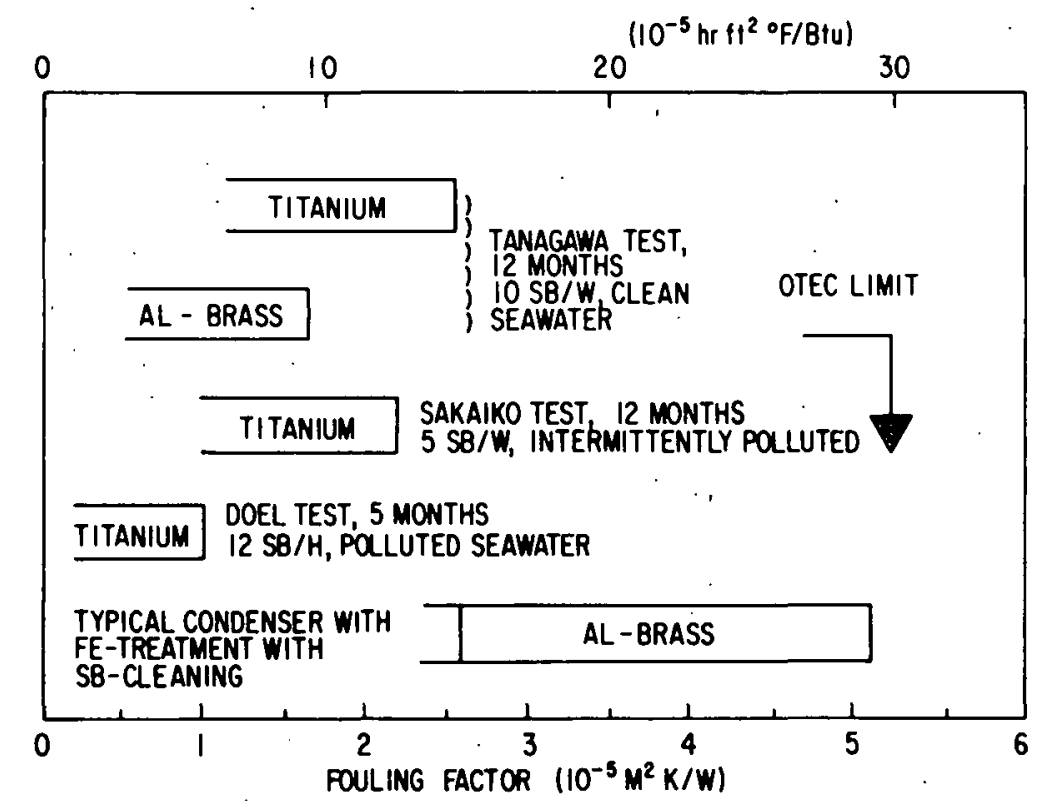

Fig. 4. Comparison of Fouling Parameters as Compared to the OTEC Limit

\footnotetext{
* Braswell, J. A., D. F. Lot and S. M. Hedlicka. Preliminary Evaluation of Flow-driven Brushes for Removal of Soft Biofouling from Heat Exchanger Tubes in OTEC Power Plants. Proceedings of the OTEC Biofouling, Corrosion and Materials Workshop, 1979.
} 
Advantages of the Amertap system are ease of high cleaning frequency, automation, considerable power-plant experience in the USA, and variability of abrasiveness through selection of ball materials. Disadvantages include dependence on random tube selection, which can be affected by changes in balls due to wear and contamination, head losses due to collection screens, complex equipment for automatically sizing sorting and counting balls, short ball life, usability only inside smooth, round walled tubes, and possible enhancement of corrosion and/or erosion of tube walls.*

Preliminary tests at Panama City, FL, have shown that the conventional Amertap system can maintain shell and tube heat exchangers. free of microfouling for short periods of time. Extensive studies of Amertap have been undertaken by the Sumitomo Light Metal Industries of Japan. They undertook a three-year test using a model condenser of a once-through type installed at their power plant, using clean seawater without chlorination. Sponge-ball cleaning alone of either aluminum brass or titanium tubes resulted in a buildup of microbiofouling. However, carborundum ball cleaning at a rate of one ball every two hours kept the titanium tubes free from fouling. Negligible corrosion of the titanium was observed at the end of the three-year period. Carborundum cleaning was not recommended for aluminum brass because of the high rate of corrosion.**

The Amertap system appears to provide a promising approach to the control of microbiofouling when used either alone or in combination with chlorination. Tests are required including Amertap with chlorination and the use of 'different balls with varying abrasive capacity. Long-term tests at the Seacoast Test Facility and elsewhere are required to determine if the optimized Amertap system suffers from buildup of plaque. In addition, it is essential to determine the relationship between effectiveness of the biofouling countermeasure used and the corrosion rate.

\section{Chemical Treatment}

Chlorination is the most commonly used biofouling control measure in the power industry. More than half a century's experience in the use of chlorine as a biocide for water and wastewater treatment has established its effectiveness as an antimicrobial agent. In the power industry, gas refineries, and other industries using large volumes of cooling water, chlorine is commonly used to prevent microbial slime formation on condenser surfaces. Usually, sufficient chlorine needs to be applied to maintain a chlorine residual of at least $0.5 \mathrm{mg} / 1(0.5 \mathrm{ppm})$. However, the concentration of chlorine applied and the frequency of application depends on the organic load in the water, the temperature, and the flow rate across the surface. Removal of established microbial films from heat exchangers requires much higher concentrations of

\footnotetext{
*Hagel, D., A. F. Conn and M. S. Rice. Methods for Cleaning OTEC Heat Exchangers. Proceedings of the OTEC Biofouling and Corrosion Symposium, 1977.

**Nosetani, T. Effect of Marine Biofouling on the Heat Transfer Performance of Titanium Condenser Tubes. Proceedings of the International Conference on Condenser Biofouling. RPI New York, 1979.
} 
chlorine, sometimes at a level of $50 \mathrm{mg} / 1 . *$ Even at these levels, the chlorine may not penetrate the slime film, and cleaning is frequently not complete.

A test program is currently being undertaken to determine the applicability of chlorine for control of microbiofouling in the OTEC program. However, realistic estimates of the amount of chlorine needed will require on-site testing. Chlorination tests at the Seacoast Test Facility and elsewhere should establish the required cleaning cycle and concentration required.

Chemical cleaning offers the important advantage of being able to clean heat exchangers of any geometry. In the event that chlorine is unacceptable, other chemicals including detergents, acid, and basic cleaning solutions, are available. Incorporation of chemical cleaning into OTEC heat exchangers would require modification to allow drainage and isolation of heat-exchanger modules to permit recycling and/or recovery and disposal of potentially harmful substances. Neither technical feasibility nor cost effectiveness have been established for this form of cleaning process. However, it is recommended that such tests be included in the countermeasures laboratory and elsewhere using compact heat exchangers.

\section{Slurry Cleaning}

Diatomaceous earth slurries have been used to clean heat exchangers in the Atlantic Richfield Companies Hanford Nuclear Power Plant. It has been suggested that slurries, especialiy sand, would provide a readily available inexpensive nonpolluting cleaning system for OTEC heat exchangers. By comparison with chemicals,"slurries offer a minimal hazard and can be disposed into the. sea. Turbidity, however, may present an environmental problem. An adequate supply of diatomaceous earth can probably not be obtained. The entire yearly production of diatomaceous earth in the United States would be needed to make a $1 \%$ slurry for a 24-h cleaning of a 100-megawatt OTEC plant.* Unless an inexpensive recovery and recirculation procedure is developed or a readily available material such as sand is found to be acceptable by tests, slurries can probably not be used to clean OTEC heat exchangers.

\section{E. Ultrasonic Cleaning}

High-intensity ultrasound has been used experimentally to destroy waterborne bacteria. The number of bacteria in a water sample can be reduced by three orders of magnitude with exposure times of 6-7 minutes. Ultrasonic oscillation has been used to kill bacteria in shipboard wastes. A minimum of 500 watts $/ \mathrm{cm}^{2}$ is required, producing local pressures as high as $75,000 \mathrm{psi}$. These pressures would probably cause serious fatigue problems on heat-exchanger metal surfaces. Tests by the Navy showed that ultrasonic transducers operating at 800 watts for periods of 10-15 seconds did not completely remove

\footnotetext{
*Rice, M. S., D. Hagel and A. F. Conn. Hydronautics Report 7707-1-1978.
}

**NCSL Technical Report No. 29576, 1976. 
bacterial slimes from surfaces.* Since partial control of microbial slimes would be unacceptable on OTEC surfaces, it seems unlikely that ultrasound would effectively control microbiofouling on OTEC heat exchangers. In addition to incomplete destruction of slime, the Navy tests showed that cleaning is not uniform. Cavitation regions were localized. on metal surfaces, and only those regions where cavitation was intense were cleaned. Obviously, the inefficiency of cleaning, cumbined with excessive electrical power requirements, makes ultrasound an unlikely candidate for OTEC heat-exchanger use.

\section{F. Plaque Formation}

Evidence is accumulating that deposits build up on heat-exchanger surfaces following extended periods of cleaning. In the three-year Japanese study, $* *$ deposits accumulated on both aluminum brass and titanium surfaces being cleaned by Amertap balls. The plaque appeared to be a mixture of microbes, their exopolymer, and inorganic debris. Decreased effectiveness of cleaning has also been observed in conventional power plants and in the OTEC countermeasures. program.

It is not known if plaque formation occurs at all locations and on all metal surfaces. Similarly, we have no information about the number of cleaning cycles required for the deposit to reach a maximal thickness. Nor do we have information about the effectiveness of either mechanical or chemical cleaning for removal of the plaque. Long-term cleaning tests will be required to determine if plaque accumulation is a problem on OTEC heat-exchanger surfaces and to establish methods of either preventing these deposits from occurring or finding a means of removing the plaque after it has developed.

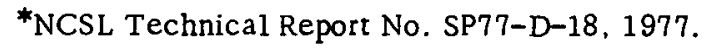

** Nosetani, T. et al. Proceedings of the International Conference on Condenser Biofouling, RPI New York, 1979. 


\section{MACROFOULING COUNTERMEASURES}

Macrofouling normally occurs on all untreated surfaces in contact with the sea. It is essential to prevent fouling growth on the insides of intake pipes, on screens, and on all seawater-wetted equipment associated with the OTEC program. The countermeasure used must be continuous, allowing protection at all times. The macrofouling hazard is maximal during periods of low flow or shutdown. If attachment of fouling larvae is not prevented during these periods, fouling will develop, increasing frictional resistance to such an extent that flow velocities will be seriously reduced. Frequently the flow is stopped completely, resulting in shutdown of equipment. Clumps of shells may be torn loose by the force of the flow and be carried through the pipes to points where they will clog pipe intakes, plug condenser tubes, block valves, and impede the flow through screens. If fouling is allowed to develop on auxiliary equipment, the entire unit will probably have to be shut down to clean out the macrofouling organisms. No single control measure for macrofouling is applicable to the entire OTEC system. Different solutions need to be developed based on the macrofouling hazard, engineering design, and other processes occurring in the system.

The need to prevent settlement of macrofouling larvae cannot be overemphasized. Once the larvae have settled, they are much more resistant to control. Adult forms are even more difficult to kill and, even if killed, leave residual dead material behind that may seriously interfere with performance of the entire OTEC system and present a disposal problem. This section of the report discusses the wide range of state-of-the-art options open for control of macrofouling. Although new processes are being continuously developed for fouling control, it is believed inappropriate to test materials or processes for OTEC use until they have been widely tested by other marine users.

\section{A. Toxic Coatings}

Conventional copper-based antifouling paints have minimum applicability to OTEC macrofouling protection. Commercial cuprous oxide paint, while performing well for short periods of time, rarely have a life of longer than 18 months. The short $1 \mathrm{i}$ fe of these paints is determined by the rapid leaching rate. In recent ycars, polyvinyls, polyacrylates, epoxy compounds, and polyurethane materials have been used as antifouling coatings. These slow-release antifouling coatings are being impregnated with copper. Some of these paints may yield 5-10 years of protection; however, none of these coatings are commercially available yet.

The organotins have a higher level of toxicity than copper-based paints. Polymers impregnated with tributyl tin oxide or fluoride may afford protection 
for as long as 10 years.* The Navy has had extensive experience with the rubber-based "No-foul" produced by Goodrich. A major problem encountered with No-foul is the thick layer and cost required for long-range protection. The leaching rate ranges from 10 to $80 \mu g$ per $\mathrm{cm}^{2}$ per day. The problem of firm bonding to the metal surface requires hand rolling. In addition, the tributyl tin oxide effluent may not degrade rapidly following leaching. The chemical, which is very toxic, may accumulate in the marine biota. It is being studied by the EPA as a potentially harmful chemical ecologically.

\section{B. Nontoxic Coatings}

Alteration of the surface has been tested as a means of controlling macrofouling. The International Paint Co. has tested a self-polishing co-polymer that ablates in flowing water, generating a self-smoothing effect. This material has not been extensively tested and may not be useful because of its inactivity when flow is low or when there is standing water in the system.

The use of low-energy surfaces has also been suggested as a means of controlling macrofouling.** Low-energy surfaces produced by fluorochemical monolayers prevented algal fouling on aluminum alloys and on titanium; however, fouling by barnacles was not prevented. The surface appeared to stimulate slime formation and accelerated macrofouling.

Macrofouling larvae are repelled by a wide range of nontoxic chemicals. The activities of these antifouling repellants is enchanced by their capacity to also prevent excessive bacterial slime formation. Nontoxic antifouling coatings based on these repellents are being developed. ${ }^{\dagger}$

The possibility of using highly polished surfaces to prevent macrofouling has been considered. However, although a polished surface is initially more resistant to fouling than a roughened one, the effect is temporary. As microbial slimes build up on the surface, it becomes roughened and susceptible to macrofouling. Within weeks, no difference can be observed between initally polished and initially rough surfaces in their susceptibility to macrofouling.

\section{Toxic Alloys}

Copper alloys have a long and successful history of use in the marine environment as antifoulants. They are strongly resistant to macrofouling and have low corrosion rates. Thus, copper alloys can be depended upon to yield some degree of long-term protection against macrofouling. The minimum level of cuprous oxide corrosion product required to maintain fouling resistance has been

*Castelli, V. "Corrosion and Biofouling on the Heat-exchanger Surfaces of an OTEC Power Plant." Report No. DTNSROC-79/054, David Taylor Naval Ship R\&D Center, Bethesda, MD, 1979.

**Ostrozynski, R. L. and P. E. Jones. DOE Report No. TID27746, 1976.

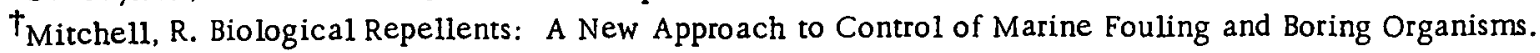
NAVSEA, July 1976. 
estimated at $5 \mathrm{mg} / \mathrm{dm}^{2} / \mathrm{day}^{*}$ In uniformly corroding copper alloys, this corresponds to a corrosion rate of about $0.8 \mathrm{mil} /$ year. Although this value is accepted as the minimum, recent work has shown that copper-nickel alloys retain their fouling resistance, even when corroding at only 0.05 to $0.1 \mathrm{mil} /$ year, since the corrosion-product film that forms on copper alloys is itself believed to be toxic.

The corrosion rate of copper and its alloys in seawater, and therefore the antifouling properties, are a function of many factors including watertemperature, velocity, oxygen content, salinity as well as alloy content, and galvanic interaction with other metals. When clean copper surfaces are initially placed in seawater they corrode at a higher rate than normal until a protective corrosion-product film is formed.** Under most conditions, this requires several weeks. Resistance to macrofouling on $90 / 10$ copper-nickel has been observed where the instantaneous corrosion rate has dropped to $0: 1 \mathrm{mil} /$ year following three to four years immersion in quiet seawater. Fouling resistance can be maintained for much longer periods by brushing the surface to remove the cupric hydroxychloride corrosion product.

The use of copper alloys for macrofouling protection requires that extra care be taken to avoid setting up galvanic couplings. Copper alloys are cathodic to most other structural metals, such as steel or aluminum. Therefore, the use of these metals in electrical contact with copper alloy must be avoided.

The use of copper alloys for protection against macrofouling provides a potentially flexible solution for some areas of OTEC. Recent work using plasmaspray techniques to apply copper metal and alloys to nonmetallic substrates has eliminated forming and attachment problems and provides further flexibility.

\section{Chlorination}

Chlorine is a strong oxidizing agent and is commonly used to control fouling in power plants. When chlorine gas or hypochloride is added to water, a mixture of hypochlorous acid (HOCl) and hydrochloric acid ( $\mathrm{HCl}$ ) is formed.

$$
\mathrm{Cl}_{2}+\mathrm{H}_{2} \mathrm{O} \rightarrow \mathrm{HOCl}+\mathrm{H}^{+}+\mathrm{Cl}^{-} \text {. }
$$

Hypochlorous acid is a weak acid and does not dissociate at levels of pH below 6. Between $\mathrm{pH} 6$ and 8.5, there is a complete dissociation according to the equation

$$
\mathrm{HOCl} \rightarrow \mathrm{H}^{+}+\mathrm{OC}^{-} \text {. }
$$

At the usual $\mathrm{pH}$ of seawater, 8.0 , there is $20 \% \mathrm{HOCl}$ relative to the amount of dissociated hypochlorite. For the invertebrate fouling organisms, the reactive

*LaQue, F. Proc. 3rd International Congress on Marine Corrosion and Fouling, 1972.

**Huguenin, J. E. and F. J. Ansuini. The Advantages and Limitations of Using Copper Materials in Marine Aquaculture. IEEE Ocean 75, p. 444. 
element is probably the strongly oxidizing $\mathrm{OC1}^{-}$or bromine compounds. It may interfere with the transfer of gases on the body surface, but the actual physiological effect is not known.*

Because of the presence of bromide ions in seawater, the compounds produced by the chlorination of seawater differ from those produced in fresh water. Seawater contains $65 \mathrm{mg} / 1$ bromide, which is oxidized by chlorine to produce a series of brominated compounds analogous to the chlorinated compounds produced in fresh water. At present, analytical methods do not exist to separate. chlorinated and brominated compounds in seawater. Thus, the traditional chlorinated nomenclature may be inappropriate for seawater. $* *$ The so-called free residual chlorine measured in seawater is probably bromamine. Similarly, "combined residual chlorine" may contain significant quantities of free bromine. However, if chlorine does not occur due to its reaction with bromide ion, then bromine determinations may be needed.

Four sources of chlorine are available to OTEC: calcium hypochlorite, liquid chlorine, liquid sodium hypochlorite, or on-site hypochlorite generation.** Liquid chlorine or chlorine gas is normally used for disinfection because of its low cost and the readily available chlorination injectors. However, chlorine gas is very poisonous and may be difficult to use in OTEC systems. Liquid sodium hypochlorite provides a safe alternative to liquid chlorine. However, the cost is much higher than the liquid form. Both liquid chlorine and sodium hypochlorite are subject to problems associated with transportation and storage. The most economical and reliable source of chlorine is on-site generation. Both electricity and the electrolyte sodium chloride are available for OTEC plants, making electrolytic chlorine production the obvious choice.

There is no concensus about the concentration of chlorine needed to control macrofouling. Similarly, no agreement has been reached about the relative advantages of low-level continuous chlorination compared to intermittent chlorination at higher concentrations. Experience has shown that the level of chlorination and the application rates depend on a variety of factors, including the predominant organisms, their growth rates, the location, season, and the water temperature. A number of power plants have reported that continuous chlorination at levels of $0.25-0.50 \mathrm{mg} / 1$ of free residual chlorine prevents the development of fouling organisms. In general, the soft macrofouling organisms can be controlled by intermittent chlorination at a level of $1.0 \mathrm{mg} / 1$ residual chlorine for one hour out of every eight hours. However, hard-shelled foulers, including barnacles and mussels, require continuous low-level chlorination. These organisms require a continuous discharge of $0.25-0.5 \mathrm{mg} / 1$ of free residual chlorine. In Great Britain, chlorine concentrations of $0.5 \mathrm{mg} / 1$ were needed to prevent hard fouling. Intermittent chlorination did not control hard-shell fouling.

*Methods of Controlling Marine Fouling in Seawater Desalination Plants, Dow Chemical Co., 1973. **Fava, J. A. and D. L. Thomas, 1978. Use of Chlorine to Control OTEC Biofouling. Ocean Engineering 5:269. 
The British Central Electricity Research Laboratories have demonstrated that low-level continuous chlorination can control fouling by masels.* They found that continuous low-level injection of chlorine at $0.5 \mathrm{mg} / 1$ produced $0.1-$ $0.05 \mathrm{mg} / 1$ of residual chlorine. They maintained the Carmarthen Bay power station free from mussel fouling for a number of years. This was the result of the specific feeding behavior of mussels. Apparently, control is achieved because mussels in lightly chlorinated water stop. feeding, resulting in ultimate starvation. This phenomenon is specific to mussels and probably cannot be used to control other macrofouling organisms.

The products of chlorination may persist in the environment of seawater discharges as chloramines. These compounds may provoke chronic and acute ecosystem damage. The Environmental Protection Agency has established allowable concentrations of free chlorine in new. steam-generation power-plant effluents as an average of $0.2 \mathrm{mg} / 1$ during a maximum of two hours per day with a maximum during these periods of $0.5 \mathrm{mg} / 1$. Thus, if chlorine is to be used in OTEC plants, the free chlorine discharged into the ambient water must be within the boundary of the EPA guidelines. In addition, economic constraints and parasitic power losses to generate hypochlorite dictate that the concentration of chlorine applied be maintained at the lowest possible level.

\section{E. Ozone}

Ozone is commonly used in Europe for disinfection of drinking waters. It is a powerful oxidizing agent with twice the oxidizing power of chlorine as a disinfectant. Ozone has been suggested as an alternative antifoulant to chlorine. However, like chlorine, ozone can produce long-lived bromoform compounds, which may be harmful to aquatic life.* Residuals decrease very slowly with time. About $3.5 \mathrm{mg} / 1$ of oxidant remain in the water after 24 hours. Other tests showed that, in seawater being treated with ozone, the residual oxidant remained in the water at a level of $4.0 \mathrm{mg} / 1$ for a week. These data suggest that the detrimental environmental effects of chlorine cannot be overcome by the use of ozone, and the power requirements of ozonation exceed those of sodium hypochlorite generation by a factor of 6 or $7 .^{\dagger}$

\section{F. Ultraviolet Irradiation}

Effective disinfection of water has been achieved using ultraviolet irradiation at a dosage of 2500-440,000 $\mu \mathrm{W}-\mathrm{sec}$ per $\mathrm{cm}^{2}$. Ultraviolet is used commercially for the sterilization of aquaculture, fish hatchery, and aquarium water. Because of the very high attenuation rate of ultraviolet light in seawater,

*Beauchamp, R. Low Level Chlorination for the Control of Marine Fouling. Report of Central Electricity Research Laboratories. U. K. No. RD/L/M447.

**Blogoslawski, W. J. and M. E. Stewart. Marine Application of Ozone Water Treatments. In Forum on Ozone :

Disinfection. Int'l Ozone Institute, Syracuse, NY, 1977.

TRice, M. S., D. Hagel and A. F. Conn. Hydronautics, Inc. Technical Report 7707-1, 1978. 
treatment is usually achieved by allowing thin films of water to flow over a large irradiated surface. At a flow velocity of $6 \mathrm{ft} / \mathrm{sec}$ and local absorption coefficients of $0.0112 \mathrm{in}^{-1}$, the desired UV radiation intensity and exposure time could be achieved by placing $U V$ tubes $5.5 \mathrm{ft}$ apart. The lamps would have to be $6.4 \mathrm{ft}$ long, and the minimum energy density required would be $16,000 \mu \mathrm{W}-$ sec per $\mathrm{cm}^{2} .^{*}$ This configuration would require about $750 \mathrm{WV}$ lamps to treat both the warm and cold water in a 368-MW power plant. This calculation is for clear water, but the number of lamps would be significantly increased by the turbidity of seawater. The operating power requirement would be about $12.4 \mathrm{MW}$, of which only $7 \%$ is emitted as useful radiation. Table 4 summarizes the initial and maintenance cost of a UV water-treatment system for a 368-MW gross OTEC plant.

TABLE 4. Initial and Operating Cost of a UV Water-treatment System for a 368-MW OTEC Plant*

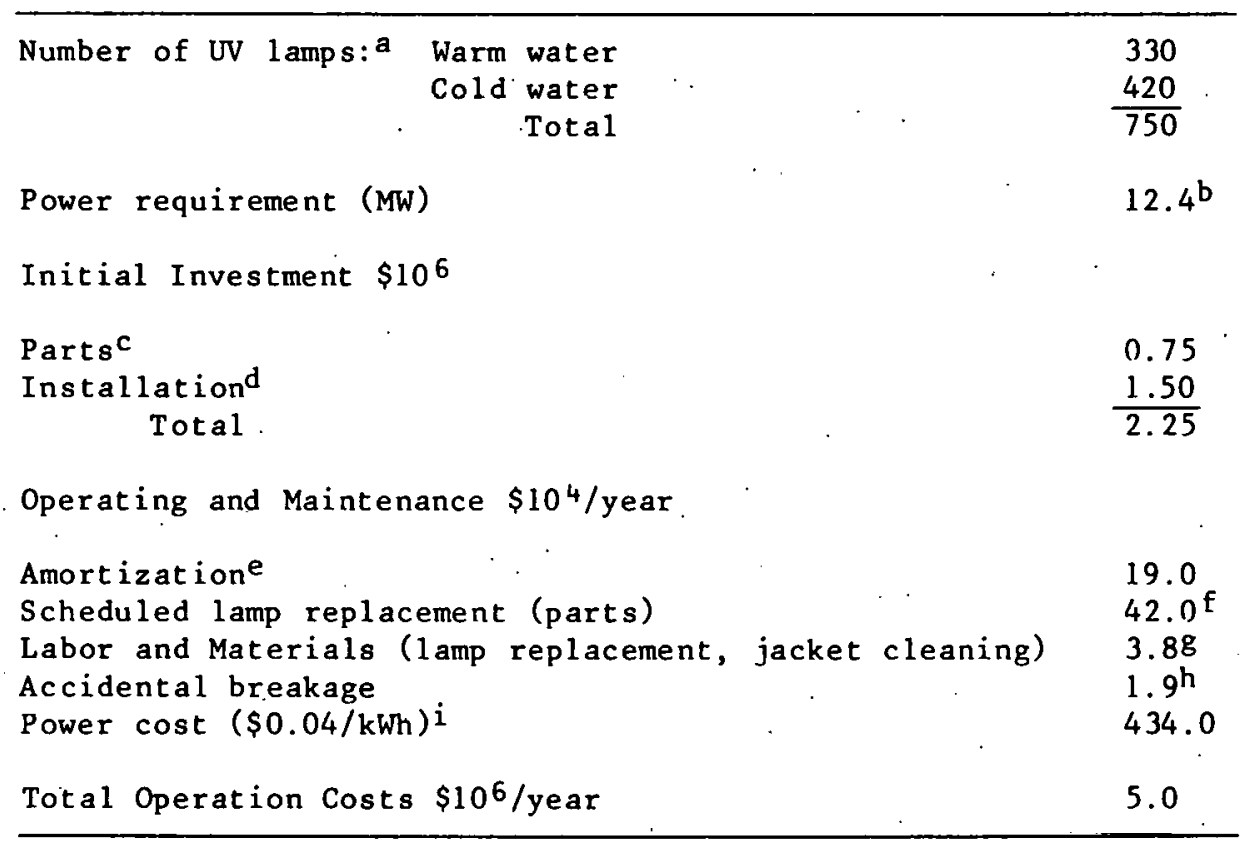

aThe required dose is assumed to be $16,000 \mu \mathrm{W}-\mathrm{sec} / \mathrm{cm}^{2}$. Calculations indicate lamp separation to be $5.5 \mathrm{ft}$. Assuming flow velocity of $6 \mathrm{ft} / \mathrm{sec}$, parallel to lamps.

bLess than $4.5 \%$ of net output.

${ }^{c}$ Assuming $\$ 1000$ per lamp, including power supply and other hardware.

dinstallation cost assumed to be double the cost of parts.

ever 20 years plus $7 \%$ yearly interest on bonds.

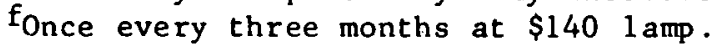

gQuartz jacket cleaning once every three months at a cost of $\$ 0.25$ per tube in materials; $15 \mathrm{~min}$ is assumed for lamp replacement at $\$ 10$ per hour.

hEach set is assumed to be replaced once during 20 years.

$i_{\text {At }} 16.5 \mathrm{~kW}$ per lamp $(10 \%$ added to account for losses at power supply), $\$ 0.04 / \mathrm{kWh}$.

*Rice, M. S., D. Hagel and A. F. Conn. Hydronautics, Inc. Technical Report 7707-1, 1978. 
Because of the high attentuation rate of UV light in seawater and the large amount of energy required, it is not recommended that UV irradiation be tested for macrofouling control. The geometry of the system would have to be altered, or an enormous number of lamps installed, to ensure adequate irradiation of surfaces to be protected. In addition, experience has shown that UV treatment would be two to three times as expensive as chlorination. The energy and economic costs might be reduced by the use of fiber optics. However, use of fiber optics would require a research and development program. Since alternative means of protecting against macrofouling are available for OTEC, it would be difficult to justify such a program.

\section{G. Ultrasonic Biofouling Prevention}

High-intensity ultrasound has been tested for the control of macrofouling. Experimental tests with this process have shown that it can be effectively used to control bacterial growth. Two types of ultrasonic transducers are currently in use: piezoelectric and magnetostrictive. The phenomenon of cavitation is used as the major source of cleaning. Typical intensities range from 6000 to 70,000 watts per $\mathrm{m}^{3}$. Although the process is highly effective in preventing fouling or cleaning fouled surfaces, the power required severely restricts the energy and cost effectiveness of the process.* Tests by the US Navy have shown that acoustic sterilizers for shipboard waste management require at least 500 watts per $\mathrm{cm}^{2}$ surfaces to kill bacteria. $* *$ In a later report the Navy showed that a fixed acoustic device for the destruction of bacteria in seawater required $1 \mathrm{~kW}$ with a flow rate of $25 \mathrm{ml} / \mathrm{sec}$. The report discussed the possibility of operating acoustic devices at $10 \mathrm{~kW}$ onboard ships. In addition to the excessive energy requirements, ultrasonic oscillation has the potential țo cause metal fatigue and/or cavitation. The evidence to date suggests that ultrasonic countermeasures for macrofouling control are not applicable to the OTEC program.

H. Cathelco

This system, manufactured by the Vickers Co. of Great Britain, uses an electrolytic process made of anodes fitted inside pipe inlets, and using a small current to prevent corrosion. Slow dissolution of the anodes is claimed to create an environment hostile to marine fouling, while drastically reducing corrosion. The power consumption is normally less than $0.25 \mathrm{~kW}$. By the action of the impressed current on a copper anode, cuprous ions are released into solution. The second anode is aluminum-forming hydrated aluminum hydroxide in the water. The aluminum hydroxide is claimed to concentrate the cuprous ions as they are liberated, forming a stable complex. Surfaces to be protected are continuously coated with a mixture of the two metals.

*Rice, M. S., D. Hagel and A. F. Conn. Hydronautics, Inc. Technical Report 7707-1, 1978.

**N. C. S. L. Technical Report 295-76, 1976. 
No detailed data about the Cathelco system are available. However, a recent study showed that the Cathelco system did not control marine fouling under the conditions of the test.* The Cathelco system may be effective at either higher flow rates or increased current densities.

$-$

I. Screens

Macrofouling on intake screen systems may be prevented by the use of a copper alloy. A fouling resistant screen for possible use in OTEC has been described.** The basic component of the screen system is a $3.3-\mathrm{ft}$ by $10-\mathrm{ft}$. fiberglass frame covered by $90 / 10$ copper nickel $3 / 8-$ in. expanded metal mesh with $76 \%$ open area. These panels are interconnected with other fiberglass structurals to form a stationary intake screen. It was suggested that, with slight modification, the panels can be used for traveling intake screens. The high water velocity, combined with the copper in the alloy, would probably serve to provide long-term protection against macrofouling. A program to test the combined effect of water velocity and alloy compositions on macrofouling needs to be initiated.

\section{J. Concrete and Plastic Structures}

Macrofouling will develop both on intake pipes and on the basic floating structures of the OTEC platform. With a flow velocity of approximately $4 \mathrm{ft} / \mathrm{sec}$ at a distance of $0.5 \mathrm{~mm}$ from the inside surface of the intake pipe, if the pipe is smooth and free of fouling, no fouling should occur because of the high velocity. However, areas of low velocity or turbulence are ideal sites for fouling organisms to settle. Once this occurs, macrofouling can spread until the entire piping system is covered. The process is much more rapid on floating structures, because the water is not flowing rapidly. It may be possible to line the inner surface of seawater intake ducts and to coat the floating structures of OTEC plants with antifouling marine concrete. Antifouling concrete has been developed at the Naval Civil Engineering Laboratory. ${ }^{\dagger}$ Concrete impregnated with TBTO or creosote remained free of macrofouling for seven years in their tests.

If fiber-reinforced plastics are used for the cold-water pipe, either organotin or other antifouling organic chemicals may be incorporated during fabrication of the plastic. The Navy is currently experimenting with organotins incorporated chemically in the cross-linking agents used to produce

*Lewis, R. O., 1980. Evaluation of the Effectiveness of a Cathelco System for Biofouling. Control under Simulated OTEC Conditions. Technical Report. LaQue Center for Corrosion Technology, Wrightsville Beach, N.C.

**Ansuini; F. J., J. E. Huguenin and K. L. Money, 1978. Fouling Resistance Screens for OTEC Plants,

Proceedings Fifth OTEC Conference.

TO'Neil, T. B. and C. W. Mathews, 1979. Anti-fouling Marine Concrete. Proceedings of the OTEC Biofouling, Corrosion and Materials Workshop. 
glass-reinforced plastics.* These glass-reinforced laminates based on organotin epoxys incorporate the antifoulant via the organotin curing agent. The physical properties of these laminates are listed in Table 5. Only a slight decrease in the strength properties occurs when organotins are incorporated into the laminates.

TABLE 5. Physical Properties of Organotin and Conventional Laminates ${ }^{a}$

\begin{tabular}{|c|c|c|c|c|c|}
\hline \multirow[b]{2}{*}{ Property } & \multicolumn{3}{|c|}{ Epoxy Laminates } & \multicolumn{2}{|c|}{ Polyester Laminates } \\
\hline & Organotin & $\begin{array}{l}\text { OMP } \\
\text { "She11" }\end{array}$ & $\begin{array}{l}\text { Conven- } \\
\text { tional }\end{array}$ & Organotin & $\begin{array}{l}\text { Conven- } \\
\text { tional }\end{array}$ \\
\hline $\begin{array}{l}\text { Flexural } \\
\text { strength, psi }\end{array}$ & 56,600 & 65,700 & 72,000 & 55,400 & 63,800 \\
\hline $\begin{array}{l}\text { Flexural } \\
\text { modulus, psi }\end{array}$ & $2.5 \times 10^{6}$ & $2.8 \times 10^{6}$ & $3.5 \times 10^{6}$ & $2.5 \times 10^{6}$ & $2.7 \times 10^{6}$ \\
\hline $\begin{array}{l}\text { Tensile } \\
\text { strength, psi }\end{array}$ & 44,000 & 48,200 & 50,500 & 43,400 & 44,800 \\
\hline $\begin{array}{l}\text { Tensile } \\
\text { modulus, psi }\end{array}$ & $2.8 \times 10^{6}$ & $3.0 \times 10^{6}$ & $3.3 \times 10^{6}$ & $3.0 \times 10^{6}$ & $3.5 \times 10^{6}$ \\
\hline $\begin{array}{l}\text { Compressive } \\
\text { strength, psi }\end{array}$ & 36,900 & 48,200 & 55,600 & 30,900 & 33,000 \\
\hline Resin content, $1 \%$ & 38 & 39 & 36 & 43.2 & 40.0 \\
\hline $\begin{array}{l}\text { Specific } \\
\text { gravity, } g / m\end{array}$ & 1.69 & 1.78 & .1 .82 & 1.90 & 1.90 \\
\hline
\end{tabular}

These materials appear to be promising for use in the OTEC program. It would be advisable to obtain further information from the Navy about antifouling plastics. In addition, it is recommended that these laminates be included in the macrofouling countermeasures program.

K. Mechanical Cleaning

In the event that fouling accumulates on OTEC surfaces, a means of mechanically removing the fouling organisms must be available. Mechanical defouling of OTEC surfaces could make use of state-of-the-art water-borne maintenance procedures developed for ship hulls. The normal method of cleaning uses multibrushed vehicles directly. or remotely controlled by divers and augmented by hand-operated rotory scrubbers. The SCAMP system developed by the EXXON corporation is a 1.8-m-diameter three-brush vehicle, which is held against the vertical surface by an independent suction impeller positioned in the center. This

*Castelli, V. J., 1979. Corrosion and Biofouling on the Non-heat-exchanger Surfaces of an Ocean Thermal Energy Conversion Power Plant, Report No. DTNSRDC-79/054. 
allows the angle brushes to skim the hull surface by a shearing action. It is propelled by two motorized rubber wheels, and a third movable wheel provides steering control. SCAMP can clean the interior of docks larger than $9 \mathrm{~m}$ in diameter.

Hydraulic jet cleaning is normally used to remove debris, loose paint, rust, and scales from ship hulls in dry dock. The jet usually delivers a stream of water at pressures up to $680 \mathrm{~atm}$ at $90 \mathrm{1} / \mathrm{min}$. Underwater cleaning can be achieved by using cavitation jets. A system developed by Daedalean Associates, Inc., operates through a range of $40,000 \mathrm{gal} / \mathrm{min}$ at $5000 \mathrm{psi}$ to $12 \mathrm{gal} / \mathrm{min}$ at $20,000 \mathrm{psi}$. The system was tested for removal of marine fouling using a , 2.24-gal/min flow rate at an operating pressure of $9000 \mathrm{psi}$ or less. It was capable of cleaning a 42-in.-diameter marine propeller in 30 minutes and removed marine growth to a bright metal finish at a rate of $60 \mathrm{ft}^{2} / \mathrm{hr}$.

The cavitating water-jet cleaning system appears to provide a promising approach to removal of macrofouling from accessible OTEC surfaces. Handheld Cavijet (Hydronautics, Inc.) guns are available.* These could be used to clean OTEC surfaces that have been fouled. It is recommended that a cavitation system be tested in the OTEC program.

*Rice, M. S., D. Hagel and A. F. Conn. Hydronautics, Inc. Technical Report 7707-1, 1978. 
Distribution for ANL/OTEC-BCM-011

Internal:

P. H. Benson (7)

J. B. Darby, Jr.

J. E. Draley (10)

B. R. T. Frost

A. P. Gavin

A. B. Krisciunas
J. J. Roberts

N. F. Sather

A. Thomas

ANL Contract File

ANL Libraries (2)

TIS Files (6)

\section{External:}

DOE-TIC, for distribution per UC-64 (400)

Manager, Chicago Operations and Regional Office, DOE

Chief, Office of Patent Counsel, DOE-CORO

President, Argonne Universities Association

J. H. Anderson, Sea Solar Power, Inc., York, Pa.

W. H. Avery, Applied Physics Lab., Johns Hopkins U.

E. J. Barsness, Westinghouse Electric Corp., Lester Pa.

J. O. Bates, Energy Technology Engineering Center, Canoga Park

K. J. Bell, Oklahoma State U.

R. A. Bonewitz, Aluminum Company of America, Alcoa Center, Pa.

R. Cohen, Div. of Central Solar Technology, USDOE

W. A. Corpe, Columbia U.

R. S. Dalrymple, Reynolds Metals Co., Richmond, Va.

G. J. Danek, Annapolis, Md.

J. Denton, TRW Systems and Energy, Redondo Beach

J. DePalma, U. S. Naval Oceanographic Office, Bay St. Louis, Miss .

S. Dexter, U. Delaware

M. D. Fraser, Intertechnology Corp., Warrenton, Va.

J. Gertz, Westinghouse Electric Corp., Lester, Pa.

S. Gronich, Div. of Central Solar Technology, USDOE

P. H. Hadley, Jr., Gibbs \& Cox, Inc., New York City

L. W. Hallanger, Research Corp., U. Hawai

W. Hartt, Florida Atlantic U.

W. E. Heronemus, U. Mass.

F. K. Hill, Applied Physics Lab., Johns Hopkins U.

J. F. Jenkins, Civil Engineering Lab., Naval Construction Battalion Center, Port. Hueneme

E. H. Kinelski, Div. of Central Solar Technology, USDOE

R. E. Lacey, Southern Research Institute

F. L. LaQue, Verona, N. J.

A. Lavi, Pitt sburgh, Pa.

T. S. Lee, International Nickel Co., Wrightsville Beach, N. C.

M. Leitner, Lockheed Missiles and Space Co., Inc., Sunnyvale,

L. Lewis, Div. of Central Solar Technology, USDOE

B. Little, NORDA, National Space Technology Lab., NSTL Station, Miss.

D. Lott, Naval Coastal Systems Center, Panama City, Fla.

R. N. Lyon, Oak Ridge National Lab.

F. Mathews, Colorado School of Mines

R. Mitche11, Harvard U. (105)

R. L. Molinari, NOAA/AMOL, Mi ami

J. Moore, Natural Energy Laboratory of Hawaii, Kailua, Kona 
50

R. S. C. Munier, Tracer Marine, Port Everglades, Fla.

J. Nicole, Arthur D. Little, Inc., Cambridge, Mass.

M. Olmsted, General Electric Co., Schenectady

S. Pohlman, Solar Energy Research Inst.

D. Price, National Oceanic and Atmospheric Administration, Rockville

W. W. Pritsky, Aluminum Company of America, Alcoa Center, Pa.

J. F. Rynewicz, Lockheed Missiles and Space Co., Inc., Sunnyvale:

D. Scasscer, U. Puerto Rico

C. F. Schrieber, Dow Chemical Co., Freeport, Tex.

B. Shelpuk, Solar Energy Research Inst.

W. Sheppard, NOAA Data Buoy Office, National Space Technology Lab., NSTL Station, Miss.

T. J. Summerson, Kaiser Aluminum and Chemical Corp., Pleasanton, Calif.

R. B. Tee 1, Chatham, N. J.

F. Vukovich, Research Triangle Inst.

J. Walsh, VSE Corp.

E. T. Wanderer, Aluminum Company of America, Alcoa Center, Pa.

R. L. Webb, Pennsylvania State U.

P. Wilde, Lawrence Berkeley Labs.

R. Williams, PRC Energy Analysis Co., McLean, Va.

D. C. White, Florida State U.

H. White, Kailua, Rona, Hawaii 